\title{
Transport of desert dust mixed with North African industrial pollutants in the subtropical Saharan Air Layer
}

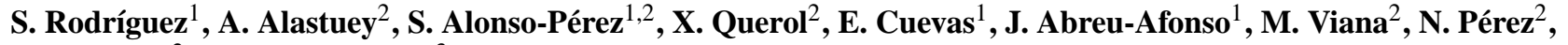 \\ M. Pandolfi ${ }^{2}$, and J. de la Rosa ${ }^{3}$ \\ ${ }^{1}$ Izaña Atmospheric Research Centre, AEMET Joint Research Unit to CSIC "Studies on Atmospheric Pollution”, La Marina, \\ 20, Planta 6, Santa Cruz de Tenerife, 38071, Canary Islands, Spain \\ ${ }^{2}$ Institute of Environmental Assessment and Water Research (IDÆA), CSIC, Jordi Girona, 18-26, 08034, Barcelona, Spain \\ ${ }^{3}$ University of Huelva, Joint Research Unit to CSIC “Air Pollution”, Campus El Carmen, 21071 Huelva, Spain
}

Received: 12 January 2011 - Published in Atmos. Chem. Phys. Discuss.: 14 March 2011

Revised: 25 June 2011 - Accepted: 27 June 2011 - Published: 13 July 2011

\begin{abstract}
An analysis of chemical composition data of particulate matter samples (TSP, $\mathrm{PM}_{10}$ and $\mathrm{PM}_{2.5}$ ) collected from 2002 to 2008 in the North Atlantic free troposphere at the Izaña Global Atmospheric Watch (GAW) observatory (Tenerife, Canary Islands) shows that desert dust is very frequently mixed with particulate pollutants in the Saharan Air Layer (SAL). The study of this data set with Median Concentrations At Receptor (MCAR) plots allowed the identification of the potential source regions of the dust and particulate pollutants. Areas located at the south of the southern slope of the Atlas mountains emerge as the most frequent source of the soil desert dust advected to the northern edge of the SAL in summer. Industrial emissions occurring in Northern Algeria, Eastern Algeria, Tunisia and the Atlantic coast of Morocco appear as the most important source of the nitrate, ammonium and a fraction of sulphate (at least $60 \%$ of the sulphate $<10 \mu \mathrm{m}$ transported from some regions) observed in the SAL. These emissions are mostly linked to crude oil refineries, phosphate-based fertilizer industry and power plants. Although desert dust emissions appear as the most frequent source of the phosphorous observed in the SAL, high $\mathrm{P}$ concentrations are observed when the SAL is affected by emissions from open mines of phosphate and phosphate based fertilizer industry. The results also show that a significant fraction of the sulphate (up to $90 \%$ of sulphate $<10 \mu \mathrm{m}$ transported from some regions) observed in the SAL may be influenced by soil emissions of evaporite minerals in well defined regions where dry saline lakes (chotts) are present. These interpretations of the MCAR plots are consistent with the results obtained with the Positive Matrix Factorization
\end{abstract}

\section{Correspondence to: S. Rodríguez} (srodriguezg@aemet.es)
(PMF2) receptor modelling. The results of this study show that North African industrial pollutants may be mixed with desert dust and exported to the North Atlantic in the Saharan Air Layer.

\section{Introduction}

Desert regions of Northern Africa are the largest source of the soil dust suspended in the atmosphere of the Earth. It is estimated that annual emissions range within the interval $300-1600 \mathrm{Tg} \mathrm{y}^{-1}$. They account for $60-70 \%$ of global desert dust emissions and they are 2-3 times larger than those of the Asian deserts, the second most important dust source region (Ginoux et al., 2004; Engelstaedter et al., 2006).

Dust plays an important role in processes affecting climate, biogeochemistry and air quality. Very briefly, the presence of dust influences the energy distribution in the atmosphere, due to its scattering and absorbing radiative properties (Haywood et al., 2003). Moreover, dust particles may act as cloud condensation nuclei and consequently they influence rain and cloud radiative properties (Levin et al., 1996). Some trace elements of dust participate in marine biogeochemical processes: the rate production of nitrate and ammonium of some cyanobacterias that utilize iron in their metabolism may be controlled by dust deposition in the ocean (Michaels et al., 1996); moreover, the Fe and P supplied by dust deposition on "high nutrient, low chlorophyll oceanic regions" may be a limiting factor for nitrogen fixation by phytoplankton (Falkowski et al., 1998; Mills et al., 2004). Consequently, dust deposition may modulate the carbon cycle. Finally, dust may also affect air quality. In urban areas affected by advections of Saharan dust, an increase in

Published by Copernicus Publications on behalf of the European Geosciences Union. 
mortality (Pérez et al., 2008; Jiménez et al., 2010) and in cardiovascular diseases (Middelton et al., 2008) has been observed.

Regional dust production and exportation in North Africa experience a marked seasonal evolution. Because of the seasonal shift of the intertropical convergence zone, the sources of soil desert dust located in Sahel are mostly activated in winter (Harmattan winds), whereas those located in northern subtropical Saharan latitudes are activated in summer (Engelstaedter et al., 2006; Sunnu et al., 2008). Thus, the so-called Saharan Air Layer (SAL) is westward exported at low "tropical" latitudes $\left(<15^{\circ} \mathrm{N}\right)$ in winter and at higher "subtropical" latitudes in summer $\left(15-30^{\circ} \mathrm{N}\right)$. This behavior can be observed in Fig. 1, where the Aerosol Index (AI) averaged for January and July is shown. AI is sensitive to the presence of UV-absorbing aerosols above $1 \mathrm{~km}$ above sea level, including mineral dust (Torres et al., 1998).

Although soil dust emissions are, by far, the most important source of the particles present in the SAL, there is increasing evidence suggesting that anthropogenic activity may be prompting changes in the amount and composition of the particles present in the SAL. Three examples are given below:

- Dust particles exported in the winter tropical SAL (Fig. 1b) are often externally mixed with carbonaceous and inorganic trace species (e.g. $\mathrm{K}^{+}$) linked to biomass burning in Sahel during the dry season (Formenti et al., 2003; Capes et al., 2008).

- A number of observations have shown that soil dust in the SAL is very often mixed with sulphate and nitrate; e.g. observations in the Canary Islands (Prospero et al., 1995; Alastuey et al., 2005; Kandler et al., 2007), Cape Verde (Formenti et al., 2003; Dall'Osto et al., 2010), Puerto Rico (Reid et al., 2003) and Barbados (Li-Jones and Prospero, 1998). The few studies focused on investigating the origin of these pollutants have shown that the transport of pollutants from Europe and their mixing with North African desert dust may contribute to the observed dust + pollutants mixing (Millán et al., 1997; Kallos et al., 1998; Gangoiti et al., 2006; Astitha et al., 2010).

- There are huge uncertainties on how human activities are changing soil dust emissions. Zender et al. (2004) defined anthropogenic soil dust as that part of the dust load that is produced by human activity. This may occur by two ways: (1) by land use which changes soil surface conditions that modify the potential for soil dust emission (e.g. by agriculture, mining, livestock, vehicles or water management), and (2) by modifying climate, which in turn modifies dust emissions, for example, by changes in surface winds or vegetation growth.

The objective of this study is to investigate the origin of some aerosol species observed in the SAL that may be in-

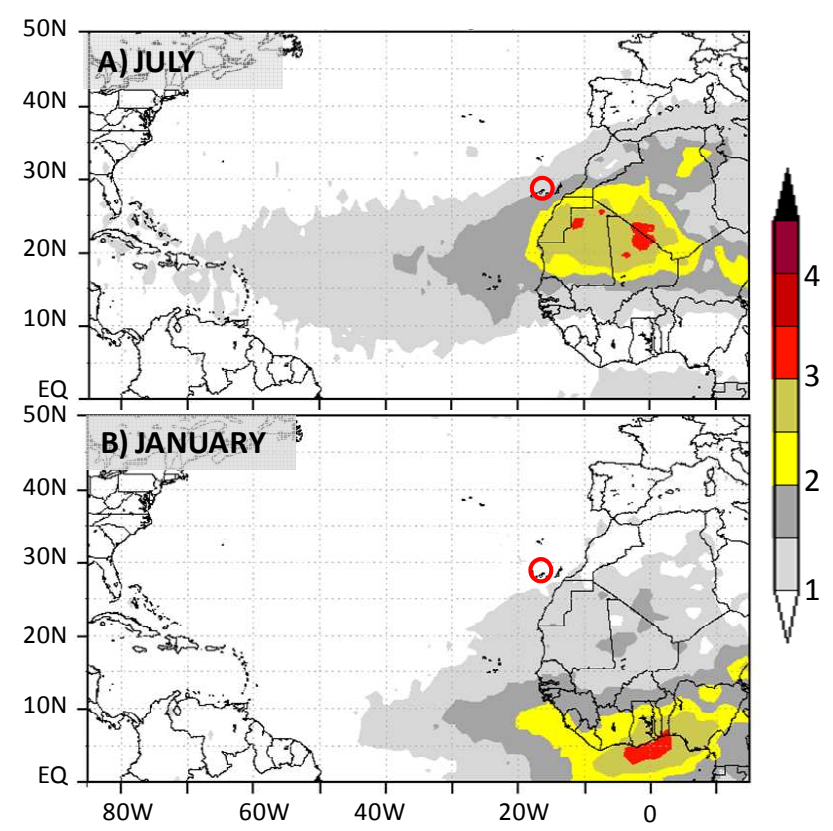

Fig. 1. Aerosol Index averaged for July and January 2008. Data recorded from Aura satellite with Ozone Monitor Instrument (OMI) and provided by Giovanni Analysis Tool of NASA.

fluenced by anthropogenic activities. We focus part of our attention on nitrate, ammonium and sulphate. The mixing of these species with dust may prompt changes in the physical properties of the SAL and this may have important consequences in processes affecting climate and air quality. For example, the coating of the dust particles with these species may enhance the hygroscopic properties and light scattering efficiency of the SAL particles (Levin et al., 1996; Li-Jones et al., 1998).

\section{Methods}

\subsection{Sampling site}

This study is based on aerosol data collected at Izaña "Global Atmospheric Watch" (GAW) observatory $\left(16^{\circ} 29^{\prime} 58^{\prime \prime} \mathrm{W}\right.$; $28^{\circ} 18^{\prime} 32^{\prime \prime} \mathrm{N}$; http://www.aemet.izana.org). This is a global important research site located in Tenerife (Canary Islands) at $2367 \mathrm{~m}$ a.s.l. (meters above sea level), above the mantle of stratocumulus typically present on the top of the marine boundary layer. Izaña remains within the SAL during most of summertime (its location is highlighted with red circle in Fig. 1). Measurements at this site are considered representative of the free troposphere. Details on the meteorological features may be found elsewhere (e.g. references within Rodríguez et al., 2009). 


\subsection{Size distribution and particulate matter sampling}

Samples of total suspended particles (TSP) and particulate matter with aerodynamic diameters smaller than 10 microns $\left(\mathrm{PM}_{10}\right)$ and 2.5 microns $\left(\mathrm{PM}_{2.5}\right)$ were systematically collected at Izaña. We will refer to this set of parameters as $\mathrm{PM}_{\mathrm{x}}$. The $\mathrm{PM}_{\mathrm{x}}$ monitoring program was based on TSP and $\mathrm{PM}_{2.5}$ from May 2002 to December 2004 and on $\mathrm{PM}_{10}$ and $\mathrm{PM}_{2.5}$ since 2005. Simultaneous TSP, $\mathrm{PM}_{10}$ and $\mathrm{PM}_{2.5}$ sampling was performed every summer since 2008 . From 2002 to 2007 each sampling lasted 24-h. Since January 2008, the $\mathrm{PM}_{\mathrm{x}}$ sampling was performed at night (22:00 to 06:00 UTC). $\mathrm{PM}_{\mathrm{X}}$ concentrations were determined by gravimetry. A total of 192 TSP, $203 \mathrm{PM}_{10}$ and $275 \mathrm{PM}_{2.5}$ samples have been collected and chemically analyzed. The sampling was performed in micro quartz fiber filters pretreated by heating to $205^{\circ} \mathrm{C}$ during $5 \mathrm{~h}$. Filter conditioning and weighing was performed following the procedure described in the EN-14907, except for RH, which was established to $35 \pm 5 \%$. Blank field filters were also collected.

Particle size distribution was measured with an Aerodynamic Particle Sizer (APS model 3321; TSI ${ }^{\mathrm{TM}}$ ) and with a Scanning Mobility Particle Sizer (SMPS model 3081; $\mathrm{TSI}^{\mathrm{TM}}$ ). Details on the in-situ aerosol characterization program of Izaña are provided online (http://gaw.empa.ch/ gawsis/ and http://www.aemet.izana.org/)

\subsection{Chemical characterization}

Thereafter, filters were analyzed by different techniques in order to determine the concentrations of about 60 elements and components. One half of the filter was bulk acidic digested (HF: $\mathrm{HClO}_{4}: \mathrm{HNO}_{3}$ ), and the solution obtained was analysed for the determination of the concentrations of major and trace elements by means of Inductively Coupled Plasma Atomic Emission Spectrometry, (ICP-AES, IRIS Advantage TJA Solutions, THERMO), and Inductively Coupled Plasma Mass Spectrometry, (ICP-MS, X Series II, THERMO), respectively. A quarter of the filter was water leached for the determination of the concentrations of soluble ions by means of Ionic Chromatography HPLC (High Performance Liquid Chromatography), for $\mathrm{Cl}^{-}, \mathrm{SO}_{4}^{2-}$ and $\mathrm{NO}_{3}^{-}$, and a ion selective electrode for $\mathrm{NH}_{4}^{+}$. Total carbon (TC) concentrations were measured by using a Total Carbon Analyser (LECO) from 2002 to 2007. Moreover, levels of organic and elemental carbon (OC and EC) were determined, in samples collected since 2007, by a thermal-optical transmission technique (Birch and Cary, 1996) using a Sunset Laboratory OCEC analyser. A set of $33 \mathrm{PM}_{10}$ samples collected during 2007 were analysed with the two techniques for inter-comparison; the good agreement found with the two techniques [OC + EC $($ SUNSET $)=0.951 \cdot$ total-carbon $($ LECO $\left.), r^{2}=0.952\right]$ guarantee a consistent continuity in the time series. Details of the analytical procedure are given by Querol et al. (2001). Relative errors of the abovementioned analysis of major species and trace elements have been estimated as lower than $10 \%$ in all the cases (Querol et al., 2008). Indirect determinations from analytical data were obtained for: (a) $\mathrm{CO}_{3}^{2-}$, calculated from the amount of $\mathrm{Ca}$ not present as $\mathrm{Ca}$-sulphate and $\mathrm{Ca}$ nitrate, and then assuming this fraction of $\mathrm{Ca}$ is present as calcite $\left(\mathrm{CaCO}_{3} ; \mathrm{CO}_{3}^{=}=1.5 * \mathrm{Ca}\right) ;$ (b) $\mathrm{SiO}_{2}$, determined from the $\mathrm{Al}$ content on the basis of prior experimental equations $\left(\mathrm{SiO}_{2}=3^{*} \mathrm{Al}_{2} \mathrm{O}_{3}\right.$, see Querol et et al., 2001). Then, dust is calculated as the sum: $\mathrm{Al}_{2} \mathrm{O}_{3}+\mathrm{SiO}_{2}+\mathrm{Fe}+\mathrm{CaCO}_{3}+\mathrm{K}+$ $\mathrm{Na}+\mathrm{P}+\mathrm{Ti}+\mathrm{Sr}$. Blank field filters were also chemically analysed.

At least one blank laboratory filter and one blank field filter were analyzed for each analysis batch. Blank levels were subtracted from the bulk concentrations determined for each sample. Filters with very low blank concentrations (according to our analysis) were used: Schleicher \& Schuell QF20 (2002-2006) and Munktell MK360 (2007-2008). The "filter + sample/blank filter" concentration ratio was within the range 10-60 for $\mathrm{Li}, \mathrm{Rb}, \mathrm{Ti}, \mathrm{Fe}, \mathrm{K}, \mathrm{S}$ and $\mathrm{Cu}$, within the range 5-10 for $\mathrm{Mn}, \mathrm{Cu}, \mathrm{Mg}, \mathrm{Co}, \mathrm{Mn}, \mathrm{Ca}, \mathrm{As}, \mathrm{Al}, \mathrm{Sr}, \mathrm{V}, \mathrm{P}, \mathrm{Ce}$ and $\mathrm{La}$, within the range $2-5$ for $\mathrm{V}, \mathrm{Na}, \mathrm{Pb}, \mathrm{Bi}$, Th, $\mathrm{Hf}, \mathrm{Sb}$, and $\mathrm{Pb}$, and within 1-2 for $\mathrm{Ni}, \mathrm{Cd}, \mathrm{Cr}, \mathrm{Cr}, \mathrm{U}, \mathrm{Sn}, \mathrm{Ba}, \mathrm{Zn}, \mathrm{Ba}$ and $\mathrm{Zn}$. For analysis control, reference material NIST $1633 \mathrm{~b}$ was added to a fraction of a blank filter to check the accuracy of the analysis of the acidic digestions: detection limit and accuracy were estimated in $0.4 \mathrm{ng} \mathrm{m}^{-3}$ and $2 \%$ for ICP-AES and $0.02 \mathrm{ng} \mathrm{m}^{-3}$ and $3 \%$ for ICP-MS. For ion chromatography and specific ion electrode, the detection limit and accuracy were $0.4 \mu \mathrm{g} \mathrm{m}^{-3}$ and $10 \%$ and $0.3 \mu \mathrm{g} \mathrm{m}^{-3}$ and $2 \%$, respectively.

From 1 January 2008, sampling was only performed at night to avoid local upslope winds during daylight. We quantified what the impact of such change was on the chemical composition of particles. For this purpose, we determined the ratios $\left[\left(\mathrm{SO}_{4}^{=} / \mathrm{Al}\right)_{2008} /\left(\mathrm{SO}_{4}^{=} / \mathrm{Al}\right)_{2006-2007}\right]$, $\left[\left(\mathrm{NO}_{3}^{-} / \mathrm{Al}\right)_{2008} /\left(\mathrm{NO}_{3}^{-} / \mathrm{Al}\right)_{2006-2007}\right]$ and $\left[\left(\mathrm{NH}_{4}^{+} / \mathrm{Al}\right)_{2008} /\left(\mathrm{NH}_{4}^{+} / \mathrm{Al}\right)_{2006-2007}\right]$ during dust events and during non dust events. During dust events, no significant changes were observed in these ratios, which exhibited values of 1.06, 0.99 and 0.94 , respectively. During non-dust events, these ratios showed values equal to $0.86,0.82$ and 0.86 , respectively, which indicates a slight decrease in the concentrations of sulphate, nitrate and ammonium when avoiding daylight sampling. The fact that the decrease in the concentrations of sulphate, nitrate and ammonium is rather low when daily sampling is avoided is in agreement with previous studies; Rodríguez et al. (2009) observed that during upslope winds nanoparticles $(<10 \mathrm{~nm}$ diameter) exhibited important increases favoured by the low concentrations of $\mathrm{PM}_{10}$ and of particles $>100 \mathrm{~nm}$ in these ascending airflows. Finally, because no significant sources of dust are present in several kilometres around the observatory (which is surrounded by volcanic rock and several $\mathrm{cm}$ size volcanic ashes locally known as picón) the change in the sampling period did not affect the dust measurements. 


\subsection{Source regions of dust and other aerosol species}

The potential source regions of dust and of other aerosol species (e.g. sulphate or nitrate) were identified by analyzing the "Median Concentrations At Receptor (MCAR)" plots determined for each aerosol species analyzed at Izaña. These MCAR plots represent the median concentrations, recorded at Izaña, of a given aerosol compound when air masses passed above each $1^{\circ} \times 1^{\circ}$ degree pixel shown in the lat $\times$ lon grid.; e.g. Fig. 10a shows the MCAR map for nitrate.

MCAR plots were determined using five days backtrajectories calculated at 00:00 UTC using the HYSPLIT software (Draxler and Rolph, 2010) and $50 \mathrm{~km} \times 50 \mathrm{~km}$ ECMWF data. MCAR plots for each aerosol compound were determined by the following steps programmed in a Matlab ${ }^{\mathrm{TM}}$ script: (1) a 3-D matrix was built, where $\mathrm{X}, \mathrm{Y}$ and $\mathrm{Z}$ dimensions correspond to lon, lat and the number back trajectories to be included in the analysis; (2) for each $Z$ value (i.e. a given back-trajectory for a specific day) the lat lon points (i.e. X-Y elements of the 2-D matrix) intersected by the trajectory were set to the value of the concentration of the aerosol species "A" recorded at Izaña; being the remaining elements of the 2-D matrix (X-Y) set to null; and (3) once all $Z$ layers have been set, the median and mean of each vector $\boldsymbol{Z}$ (i.e. fixed lat-lon, $\mathrm{X}-\mathrm{Y}$, point) were determined and then plotted (e.g. Figs. 8, 10 and 14).

MCAR plots were determined for each aerosol compound analyzed in $\mathrm{PM}_{10}$ (2005-2008). High concentrations of a given aerosol compound on a specific region of the MCAR plot is attributed to significant emission or formation rates of that aerosol species in that area.

\subsection{Sources of information}

MCAR plots were interpreted using a wide variety of sources. The location and nature of mining and industrial activities were identified using the Mineral Yearbooks of the US Geological Survey (Newman, 2008; Taib, 2008a, b) and online information on power plants, refineries and chemical plants (e.g. http://www.mining-technology.com, http://www-wds.worldbank.org, http://www.wikipedia.com or http://www.afribiz.info/). These sources were then identified and located in Google Earth ${ }^{\mathrm{TM}}$ and Google Map ${ }^{\mathrm{TM}}$. Similarly, the geographical and geomorphologic features of the observed source regions of dust were characterised using Atlases and Google Earth ${ }^{\mathrm{TM}}$ and Google Map ${ }^{\mathrm{TM}}$. Table 1 and Fig. 2 provide the location and information about the industrial sources and mining areas. The coordinates of the identified sources of dust and other aerosols is provided in order that the reader may use Google Earth ${ }^{\mathrm{TM}}$ and Google Map ${ }^{\mathrm{TM}}$ for having a satellite view. In many cases, Google Earth ${ }^{\mathrm{TM}}$ includes a link to pictures performed in-situ and available in Panoramio $^{\mathrm{TM}}$ (https://www.panoramio.com).

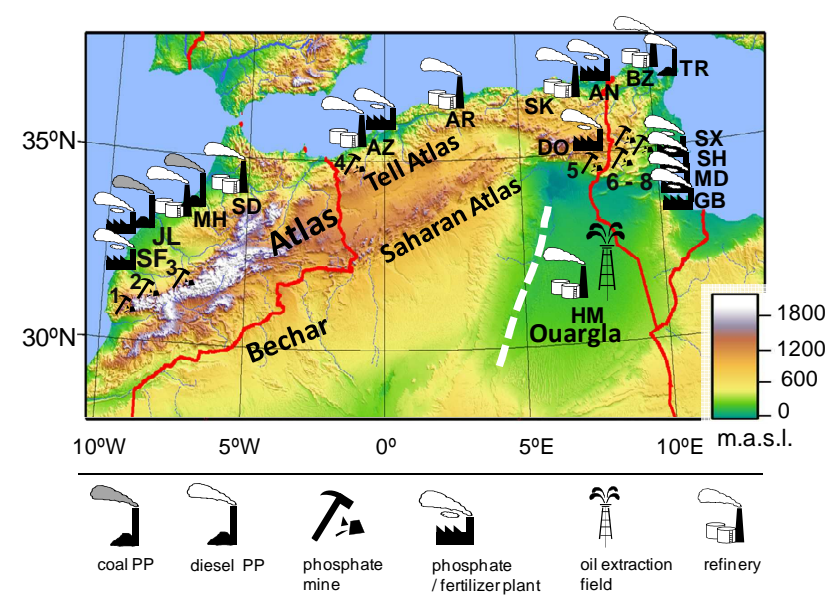

Fig. 2. Location of industrial areas and phosphate mines in Morocco, Algeria and Tunisia. PP: power plant. See Table 2 for acronyms.

\subsection{Positive Matrix Factorization}

The identification of the chemical profile of the potential sources contributing to $\mathrm{PM}_{10}$ levels and composition was identified by analyzing the $\mathrm{PM}_{10}$ composition data set with the Positive Matrix Factorization model, version 2 (PMF2; Paatero, 1997). PMF model is a factor analytical tool that provides the chemical profile and contribution of the identified sources to each aerosol constituent (Paatero and Tapper, 1994; Paatero, 1997).

The PMF model solves the matrix problem $\mathbf{X}=\mathbf{G} \times \mathbf{F}+\mathbf{E}$ where $\mathbf{X}$ is the matrix of daily chemical speciated data while $\mathbf{G}$ and $\mathbf{F}$ are the unknown matrixes of factor scores (source contribution) and loading (source profile), respectively, and $\mathbf{E}$ is the matrix of residuals (difference between measured and calculated species concentrations). The problem is solved by minimizing the objective function $Q=\mathbf{E} / \mathbf{S}$ where $\mathbf{S}$ is the matrix of the uncertainty in each data value. The minimization of $Q$ is based on the error-weighted leastsquares method, thus the calculation of the matrix $\mathbf{S}$ is a crucial point so that the model gives the right weight to the input data and consequently the most reliable results. In the present study, the matrix $\mathbf{S}$ was calculated following the procedure described in Amato et al. (2009) and Escrig et al. (2009). With this method the uncertainties of the analytical procedures described in the Sect. 2.3 are propagated jointly with the uncertainty related with the subtraction of the blank filters that are different filters from the sampled ones. The applied formula gives higher relative errors for small concentration data near the limit of detection. Once the uncertainties were calculated the number of species used within the PMF model was selected by looking at their signal-to-noise ratio $(S / N)$ which provides a criterion to separate the species which retain a significant signal from the ones dominated by noise. 
Table 1. Location and characteristics of the main industries and phosphate mines in Morocco, Algeria and Tunisia. Ac: Acronymous.

\begin{tabular}{|c|c|c|c|}
\hline Name & Ac. & Location & Activity \\
\hline SIDI KASSEM & SD & $34.233^{\circ} \mathrm{N}, 5.718^{\circ} \mathrm{W}$ & Oil refinery, $30000 \mathrm{bpd}$ \\
\hline MOHAMMEDIA & MH & $33.686^{\circ} \mathrm{N}, 7.426^{\circ} \mathrm{W}$ & Oil refinery; 125000 bpd \\
\hline MOHAMMEDIA & $\mathrm{MH}$ & $33.682^{\circ} \mathrm{N}, 7.435^{\circ} \mathrm{W}$ & Coal power plant $(600 \mathrm{Mw})$ \\
\hline JORF LASFER & $\mathrm{JL}$ & $33.105^{\circ} \mathrm{N}, 8.637^{\circ} \mathrm{W}$ & Coal power plant $(1400 \mathrm{Mw})$ \\
\hline JORF LASFER & $\mathrm{JL}$ & $33.111^{\circ} \mathrm{N}, 8.606^{\circ} \mathrm{W}$ & $\begin{array}{l}\text { Fertilizer: production of } \\
\text { - phosphoric acid } \\
\text { - ammonium phosphate }\end{array}$ \\
\hline SAFI & SF & $32.222^{\circ} \mathrm{N}, 9.249^{\circ} \mathrm{W}$ & $\begin{array}{l}\text { Fertilizer: production of } \\
\text { - phosphoric acid } \\
\text { - ammonium phosphate }\end{array}$ \\
\hline ARZEW & $\mathrm{AZ}$ & $35.812^{\circ} \mathrm{N}, 0.265^{\circ} \mathrm{W}$ & $\begin{array}{l}\text { Oil refinery }(60000 \mathrm{bpd}) \text {, petro-chemistry } \\
\text { and fertilizer production }\end{array}$ \\
\hline ALGIER & $\mathrm{AR}$ & $36.760^{\circ} \mathrm{N}, 3.065^{\circ} \mathrm{E}$ & Oil refinery $(60000 \mathrm{bpd})$ \\
\hline SKIKDA & SK & $36.880^{\circ} \mathrm{N}, 6.958^{\circ} \mathrm{E}$ & Oil refinery $(300000 \mathrm{bpd})$ \\
\hline ANABAS & $\mathrm{AN}$ & $36.871^{\circ} \mathrm{N}, 7.762^{\circ} \mathrm{E}$ & $\begin{array}{l}\text { Fertilizer. Production of: } \\
\text { - sulphuric acid, } \\
\text { - phosphoric acid, } \\
\text { - diamonium phosphate, }\end{array}$ \\
\hline DJEBE ONK & DO & $34.705^{\circ} \mathrm{N}, 7.973^{\circ} \mathrm{E}$ & phosphate rock processing \\
\hline BIZERTE & $\mathrm{BZ}$ & $37.258^{\circ} \mathrm{N}, 9.885^{\circ} \mathrm{E}$ & Oil refinery $(35000 \mathrm{bpd})$ \\
\hline RADES & TR & $36.799^{\circ} \mathrm{N}, 10.286^{\circ} \mathrm{E}$ & Diesel and gas power plants \\
\hline SFAX & SX & $34.729^{\circ} \mathrm{N}, 10.776^{\circ} \mathrm{E}$ & Phospohric acid and fertilizer production \\
\hline SKHIRA & $\mathrm{SH}$ & $34.346^{\circ} \mathrm{N}, 10.147^{\circ} \mathrm{E}$ & Phospohric acid \\
\hline M'DHILLA & MD & $34.235^{\circ} \mathrm{N}, 8.643^{\circ} \mathrm{E}$ & Phospohric acid and fertilizer production \\
\hline GABES & GB & $33.917^{\circ} \mathrm{N}, 10.093^{\circ} \mathrm{E}$ & $\begin{array}{l}\text { Phospohric acid, fertilizer and ammonium } \\
\text { nitrate production }\end{array}$ \\
\hline Khouribga & & $32.662^{\circ} \mathrm{N}, 6.703^{\circ} \mathrm{W}$ & Phosphate rock mine \\
\hline Benguerir/Yousoufia & & $32.270^{\circ} \mathrm{N}, 7.837^{\circ} \mathrm{W}$ & Phosphate rock mine \\
\hline Meskala & & $31.366^{\circ} \mathrm{N}, 9.477^{\circ} \mathrm{W}$ & Phosphate rock mine \\
\hline Djebeonk & & $34.705^{\circ} \mathrm{N}, 7.973^{\circ} \mathrm{E}$ & Phosphate rock mine \\
\hline Al Mitlawi & & $34.390^{\circ} \mathrm{N}, 8.355^{\circ} \mathrm{E}$ & Phosphate rock mine \\
\hline Umm Al Alaris & & $34.525^{\circ} \mathrm{N}, 8.265^{\circ} \mathrm{E}$ & Phosphate rock mine \\
\hline Al Rudayyif & & $34.389^{\circ} \mathrm{N}, 8.250^{\circ} \mathrm{E}$ & Phosphate rock mine \\
\hline
\end{tabular}

Only species with $S / N$ values higher than 2 were selected for the present study, thus weak species were not introduced in the model (Paatero and Hopke, 2003). Moreover, since $S / N$ is sensitive to sporadic values much higher than the level of noise, the percentage of data above detection limit (\%ADL) was used as complementary criterion for species selection. The combination of both criteria resulted in the selection of 21 species for the PMF2 analysis with averaged $S / N, \%$ ADL and relative error of major elements ranging respectively between 2.0, $32 \%$ and $85 \%$ for $\mathrm{Cl}-$ and $8.4,70 \%$ and $14 \%$ for $\mathrm{Ca}$. For trace elements $S / \mathrm{N}, \% \mathrm{ADL}$ and relative error between $2.0,30 \%$ and $80 \%$ for $\mathrm{Sb}$ and $8.5,70 \%$ and $14 \%$ for $\mathrm{Ti}$, respectively, were calculated. In order to avoid bias in the results the data matrix was uncensored, i.e. negative or below detection limit values were included as such in the analysis without substituting them with below detection limit indicators (Paatero, 1997). Once the input data and errors matrices were prepared the PMF2 model was run in robust mode (Paatero, 1997) for source identification and apportionment. The optimal number of sources was selected by inspecting the variation of $Q$ from PMF with varying number of sources (from 2 to 4 ) and by studying the physical meaningfulness of the calculated factors. Because Izaña is a remote site, the aerosol sampled at this observatory is aged and very well mixed. Consequently, only a limited number of sources can be expected from PMF analysis. In the present work a 3-factor solution was selected. The theoretical value of $Q$ should be approximately equal to the number of degrees of freedom of the system $[n \times m-(p \times(n-m)]$ (Paatero et al., 2002) where $n, m$ and $p$ are the number of samples, species and factors respectively. In our case the degrees of freedom were $3766(k=2), 3591 \quad(k=3)$, and $3416(k=4)$ for $i$ and $j$ of 196 and 21 respectively, while the calculated $Q$ were $5742(k=2), 3818(k=3)$, and 2901 
Table 2. Cross correlation matrix of $\mathrm{PM}_{10}$ components at Izaña.

\begin{tabular}{|c|c|c|c|c|c|c|c|c|c|c|c|c|c|c|c|c|c|c|c|c|c|c|}
\hline & $\mathrm{PM}_{10}$ & $\mathrm{Al}$ & $\mathrm{Fe}$ & K & $\mathrm{Mg}$ & $\mathrm{Ca}$ & $\mathrm{Na}$ & $\mathrm{Cl}$ & $\mathrm{SO}_{4}^{=}$ & $\mathrm{NO}_{3}^{-}$ & $\mathrm{NH}_{4}^{+}$ & $\mathrm{La}$ & $\mathrm{Ti}$ & $\mathrm{P}$ & V & $\mathrm{Mn}$ & $\mathrm{Sr}$ & Co & $\mathrm{Cr}$ & As & $\mathrm{Pb}$ & $\mathrm{Ni}$ \\
\hline $\mathrm{PM}_{10}$ & 1.00 & & & & & & & & & & & & & & & & & & & & & \\
\hline $\mathrm{Al}$ & 0.98 & 1.00 & & & & & & & & & & & & & & & & & & & & \\
\hline $\mathrm{Fe}$ & 0.98 & 0.99 & 0.49 & & & & & & & & & & & & & & & & & & & \\
\hline $\mathrm{K}$ & 0.98 & 0.97 & 0.53 & 1.00 & & & & & & & & & & & & & & & & & & \\
\hline $\mathrm{Mg}$ & 0.98 & 0.96 & 0.54 & 1.00 & 1.00 & & & & & & & & & & & & & & & & & \\
\hline $\mathrm{Ca}$ & 0.91 & 0.87 & 0.52 & 0.95 & 0.97 & 1.00 & & & & & & & & & & & & & & & & \\
\hline $\mathrm{Na}$ & 0.76 & 0.70 & 0.78 & 0.79 & 0.80 & 0.82 & 1.00 & & & & & & & & & & & & & & & \\
\hline $\mathrm{Cl}$ & 0.65 & 0.61 & 0.41 & 0.68 & 0.69 & 0.71 & 0.68 & 1.00 & & & & & & & & & & & & & & \\
\hline $\mathrm{SO}_{4}=$ & 0.91 & 0.89 & 0.53 & 0.93 & 0.93 & 0.91 & 0.80 & 0.66 & 1.00 & & & & & & & & & & & & & \\
\hline $\mathrm{NO}_{3}^{-}$ & 0.71 & 0.75 & 0.31 & 0.68 & 0.68 & 0.55 & 0.44 & 0.50 & 0.71 & 1.00 & & & & & & & & & & & & \\
\hline $\mathrm{NH}_{4}^{+}$ & 0.40 & 0.42 & 0.07 & 0.36 & 0.36 & 0.28 & 0.16 & 0.41 & 0.44 & 0.62 & 1.00 & & & & & & & & & & & \\
\hline $\mathrm{La}^{4}$ & 0.96 & 0.98 & 0.48 & 0.94 & 0.92 & 0.82 & 0.64 & 0.55 & 0.85 & 0.74 & 0.39 & 1.00 & & & & & & & & & & \\
\hline $\mathrm{Ti}$ & 0.98 & 0.99 & 0.48 & 0.96 & 0.95 & 0.85 & 0.67 & 0.58 & 0.87 & 0.75 & 0.41 & 0.99 & 1.00 & & & & & & & & & \\
\hline $\mathrm{P}$ & 0.95 & 0.96 & 0.50 & 0.94 & 0.92 & 0.83 & 0.68 & 0.62 & 0.87 & 0.76 & 0.45 & 0.94 & 0.94 & 1.00 & & & & & & & & \\
\hline V & 0.95 & 0.96 & 0.49 & 0.93 & 0.92 & 0.84 & 0.67 & 0.55 & 0.86 & 0.70 & 0.34 & 0.98 & 0.98 & 0.92 & 1.00 & & & & & & & \\
\hline $\mathrm{Mn}$ & 0.98 & 0.99 & 0.58 & 0.97 & 0.96 & 0.86 & 0.73 & 0.61 & 0.88 & 0.74 & 0.40 & 0.98 & 0.98 & 0.95 & 0.96 & 1.00 & & & & & & \\
\hline $\mathrm{Sr}$ & 0.96 & 0.93 & 0.53 & 0.98 & 0.99 & 0.98 & 0.82 & 0.68 & 0.93 & 0.63 & 0.29 & 0.89 & 0.89 & 0.89 & 0.91 & 0.92 & 1.00 & & & & & \\
\hline Co & 0.96 & 0.95 & 0.71 & 0.95 & 0.95 & 0.89 & 0.84 & 0.62 & 0.89 & 0.65 & 0.29 & 0.93 & 0.93 & 0.90 & 0.92 & 0.96 & 0.93 & 1.00 & & & & \\
\hline $\mathrm{Cr}$ & 0.38 & 0.36 & 0.38 & 0.37 & 0.37 & 0.37 & 0.31 & 0.29 & 0.31 & 0.31 & 0.02 & 0.36 & 0.36 & 0.39 & 0.36 & 0.39 & 0.40 & 0.38 & 1.00 & & & \\
\hline As & 0.95 & 0.93 & 0.54 & 0.96 & 0.97 & 0.94 & 0.78 & 0.65 & 0.91 & 0.63 & 0.31 & 0.90 & 0.90 & 0.87 & 0.91 & 0.92 & 0.96 & 0.93 & 0.41 & 1.00 & & \\
\hline $\mathrm{Pb}$ & 0.57 & 0.53 & 0.77 & 0.55 & 0.55 & 0.53 & 0.66 & 0.46 & 0.56 & 0.39 & 0.14 & 0.52 & 0.52 & 0.58 & 0.53 & 0.58 & 0.57 & 0.65 & 0.60 & 0.58 & 1.00 & \\
\hline $\mathrm{Ni}$ & 0.54 & 0.51 & 1.00 & 0.53 & 0.54 & 0.52 & 0.78 & 0.41 & 0.53 & 0.31 & 0.07 & 0.48 & 0.48 & 0.50 & 0.49 & 0.58 & 0.53 & 0.71 & 0.38 & 0.54 & 0.77 & 1.00 \\
\hline
\end{tabular}

$(k=4)$. For $k=4$ the above condition was not satisfied as the $Q$ calculated from the PMF was smaller than the theoretical value of $Q$, i.e. the model simulated the data better than the errors allowed. Moreover, in the four-factor solution the additional factor did not have a meaningful chemical profile being loaded with almost all used species. One additional criteria used to evaluate the meaningfulness of the calculated sources was the inspection of the ratios between specific compounds pairs in the calculated chemical profiles. As shown in subsequent sections of this paper the values of the selected ratios in the calculated chemical profiles with the three-factor solution were very close to the corresponding ratios calculated starting from the ambient experimental data. Moreover, in the three-factor solution $90-100 \%$ of the scaled residuals were located between the optimal range -2 and +2 (Juntto and Paatero, 1994).

Once the number of sources was selected the rotational ambiguity was handled by means of the $F_{\text {peak }}$ parameter (Paatero et al., 2005) by studying the variation in the $\mathrm{Q}$ values by varying $F_{\text {peak }}$ from -0.8 and +0.8 . It was found that $Q$ was minimized without rotations and an $F_{\text {peak }}$ of 0.0 was selected for the final PMF solution.

After regression of the factor scores from PMF ( $G$ matrix) to PM mass the model was able to simulate $98 \%$ of measured PM mass with a coefficient of determination of 0.99 .

\section{Results}

\subsection{Particulate matter composition}

Figure 3 a shows concentrations of aluminum and of bulk $\mathrm{PM}_{10}$ recorded at Izaña. $\mathrm{Al}$ is included as soil dust tracer (clay mineral). Concentrations of $\mathrm{PM}_{10}$ experience a large variability. During non dusty conditions $\mathrm{PM}_{10}$ typically shows concentrations within the range $1-5 \mu \mathrm{g} \mathrm{m}^{-3}$. This is the predominant situation during most of the year: "clean free troposphere" conditions. The simultaneous increases in $\mathrm{PM}_{10}$ and in $\mathrm{Al}$ concentrations registered at Izaña indicates that increases in the aerosol mass above the clean free troposphere background are prompted by the advections of Saharan dust, when $\mathrm{PM}_{10}$ may reach values as high as $150 \mu \mathrm{g} \mathrm{m}^{-3}$ (as 8-h or 24-h average). Other chemical compounds, such as $\mathrm{Ca}, \mathrm{Fe}, \mathrm{K}, \mathrm{Mg}, \mathrm{V}, \mathrm{Ni}, \mathrm{La}, \mathrm{Co}, \mathrm{Cr}$ or As, exhibit a time evolution similar to those observed in $\mathrm{Al}$ (not shown graphically). Observe in Table 2 how all compounds analyzed in $\mathrm{PM}_{10}$ exhibit a moderate to high correlation with $\mathrm{Al}$.

We compared the chemical profile of dust we obtained at Izaña (ratios to Al, Table 3) with that observed in Saharan dust samples collected in previous studies performed at Izaña (Kandler et al., 2007), Niger (Formenti et al., 2008), Cape Verde (Formenti et al., 2003) and Puerto Rico (Reid et al., 2003). Our observations are very similar to those previous observations at those sites. The overall data analysis shows that the $\mathrm{Fe} / \mathrm{Al}$ and $\mathrm{K} / \mathrm{Al}, \mathrm{Mg} / \mathrm{Al}$ and $\mathrm{Ca} / \mathrm{Al}$ ratios exhibit a relatively low variability, with average values of $0.55 \pm 0.03$, $0.21 \pm 0.01,0.18 \pm 0.03$ and $0.41 \pm 0.08$, respectively. Similar Fe/Al ratios were also observed in $\mathrm{PM}_{2.5}$ and $\mathrm{PM}_{2.5-10}$ particles collected in Florida during dust events (Prospero et al., 2001). Unfortunately, no direct measurements of the sulphate, nitrate or ammonium ratios to aluminum were found in the literature to be compared with those we observed during dust events at Izaña. We then estimated those ratios at Barbados, assuming the mean content of $\mathrm{Al}$ in soil (6$8 \%$; Prospero, 1999) and the sulphate, nitrate, ammonium and dust (gravimetrically determined) concentrations in TSP 

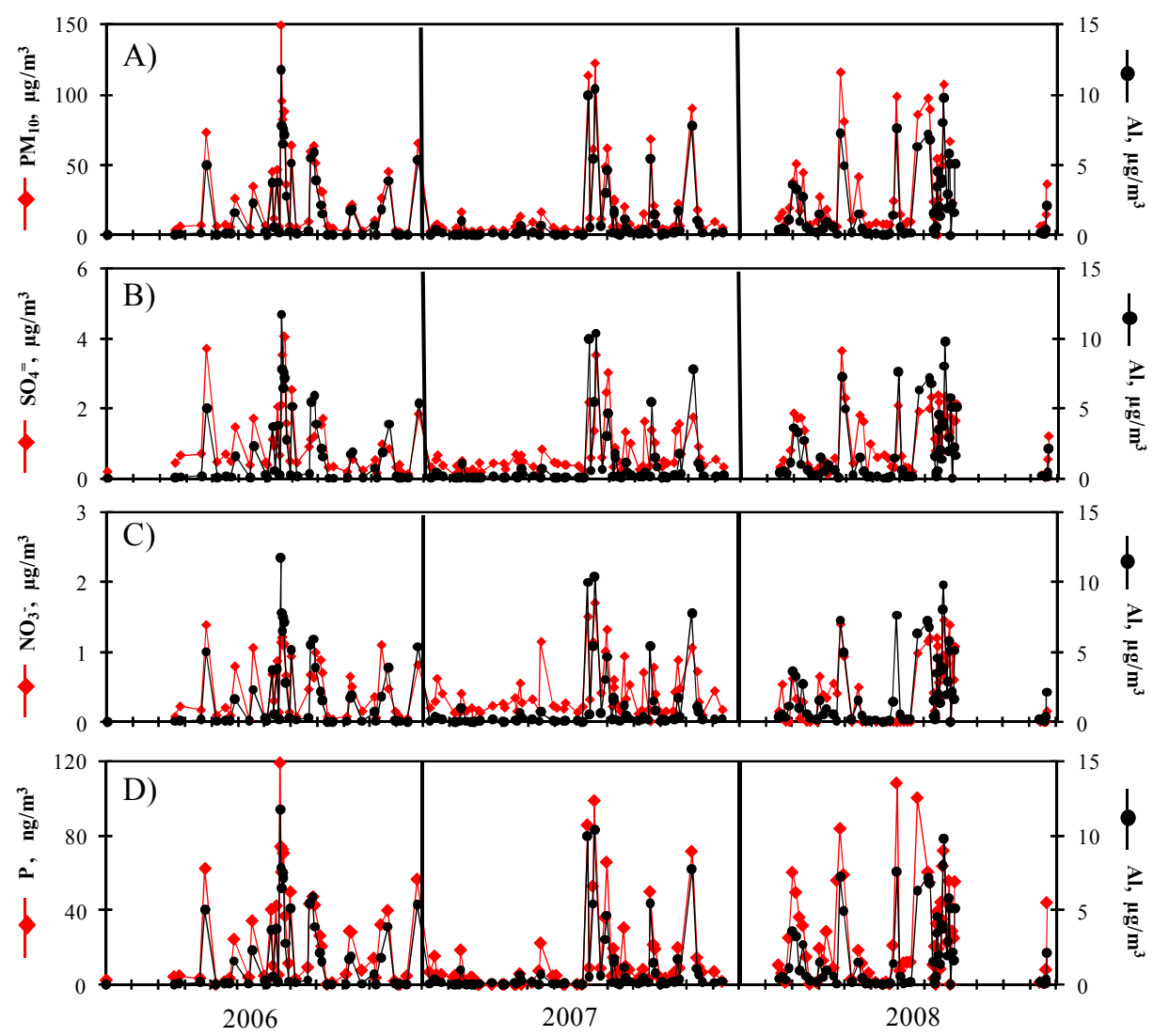

Fig. 3. Concentrations of $\mathrm{PM}_{10}$, aluminium, sulphate and nitrate recorded at Izaña.

provided by Prospero, Savoie and collaborators (Savoie et al., 1992; Li-Jones and Prospero, 1998). For mean contents of $\mathrm{Al}$ in soil within the range 8-6\%, sulphate, nitrate and ammonium ratios to $\mathrm{Al}$ within the range $0.23-0.31,0.12-$ 0.16 and $0.02-0.03$ were found, respectively. Although this estimation may be subject to significant uncertainties, it is important to highlight that these values are close to those we observed at Izaña for TSP (Table 3). The fact that the ratios at Barbados are slightly lower than at Izaña, may be linked to the regional variability of the dust and pollutants mixings.

Sulphate and nitrate in the $\mathrm{PM}_{10}$ fraction exhibited a behavior similar to that of bulk $\mathrm{PM}_{10}$ concentrations: low concentrations under clean free troposphere conditions and high levels during dust events (Fig. $3 b$ and c). The behavior we have described for $\mathrm{PM}_{10}$ is also observed in TSP and $\mathrm{PM}_{2.5}$. High concentrations of TSP and $\mathrm{PM}_{2.5}$, and sulphate and nitrate contained in these particle cut-sizes, are also recorded within the Saharan Air Layer, with daily mean concentrations of up to $700 \mu \mathrm{g} \mathrm{m}^{-3}$ of TSP and of $120 \mu \mathrm{g} \mathrm{m}^{-3}$ of $\mathrm{PM}_{2.5}$ were measured (not shown for the sake of brevity). In fact, $\mathrm{SO}_{4}^{=}$ and $\mathrm{Al}$ showed a significant positive correlation in the three $\mathrm{PM}_{\mathrm{x}}$ fractions (Fig. $4 \mathrm{~b}$ and $4 \mathrm{c}$ ).
Table 4a shows the mean composition of TSP, $\mathrm{PM}_{10}$ and $\mathrm{PM}_{2.5}$ during events in which these parameters showed bulk mass concentration data within the percentile intervals 110th, 55-85th and 85-99th, representative of clean free troposphere, moderate dust events and intense dust conditions, respectively. The increase in dust concentrations throughout the sequence clean free troposphere, moderate dust and intense dust conditions (e.g. $\sim 0.4,19$ and $70 \mu \mathrm{g} \mathrm{m}^{-3}$ in $\mathrm{PM}_{10}$ ) is associated with an increase in the absolute concentrations of sulphate (e.g. $\sim 0.3,1.2$ and $2.4 \mu \mathrm{g} \mathrm{m}^{-3}$ in $\mathrm{PM}_{10}$ ), nitrate (e.g. $\sim 0.1,0.6$ and $1.2 \mu \mathrm{g} \mathrm{m}^{-3}$ in $\mathrm{PM}_{10}$ ) and ammonium (e.g. 0.06, 0.1 and $0.3 \mu \mathrm{g} \mathrm{m}^{-3}$ in $\mathrm{PM}_{10}$ ), although a decrease in their relative contribution $(\%)$ to $\mathrm{PM}_{\mathrm{x}}$ is observed. During dust events, sulphate, nitrate and ammonium accounted for $2-6 \%, 1-2 \%$ and $0.1-0.6 \%$ of bulk $\mathrm{PM}_{\mathrm{x}}$, respectively. Organic matter and elemental carbon (e.g. 1.6, 2.9 and $3.8 \mu \mathrm{g} \mathrm{m}^{-3}$ in $\mathrm{PM}_{10}$ ) also showed a clear increase during dust events, however their behavior and sources will not be discussed here. Finally, the much higher correlation of $\mathrm{Cl}^{-}$with $\mathrm{Al}$ than with $\mathrm{Na}$ evidences a low influence of sea salt (as already described by Putaud et al., 2000).

Figure $4 \mathrm{a} 1-\mathrm{a} 3$ show the concentrations of sulphate versus ammonium expressed in equivalents. A clear excess of $\mathrm{SO}_{4}^{=}$with respect to $\mathrm{NH}_{4}^{+}$is observed in the three $\mathrm{PM}_{\mathrm{x}}$ 
Table 3. Mass ratio of concentration of selected elements with respect to aluminum (X/Al) and $r^{2}$ coefficient of the $\mathrm{X}$ versus $\mathrm{Al}$ plot for several aerosol components (where $\mathrm{X}$ is any aerosol element/component). ${ }^{*}$ : data collected in this study. ${ }^{1-4}$ : data collected in previous studies. ${ }^{1}$ Kandler et al. (2007), ${ }^{2}$ Formenti et al. (2008), ${ }^{3}$ Reid et al. (2003), ${ }^{4}$ Formenti et al. (2003). Ratio of major and trace elements/compounds are shown in $\mu \mathrm{g} / \mu \mathrm{g}$ and $\mathrm{ng} / \mu \mathrm{g}$, respectively.

\begin{tabular}{|c|c|c|c|c|c|c|c|c|c|c|}
\hline & \multicolumn{2}{|c|}{$\begin{array}{c}\text { TSP } \\
\text { Izaña* }\end{array}$} & \multicolumn{2}{|c|}{$\begin{array}{l}\mathrm{PM}_{10} \\
\text { Izaña* }\end{array}$} & \multicolumn{2}{|c|}{$\begin{array}{l}\mathrm{PM}_{2.5} \\
\text { Izaña* }\end{array}$} & \multirow{2}{*}{$\begin{array}{l}\mathrm{PM}_{1-10} \\
\text { Izaña }^{1} \\
\text { X/Al }\end{array}$} & \multirow{2}{*}{$\begin{array}{l}\text { TSP } \\
\text { Niger }^{2} \\
\text { X/Al }\end{array}$} & \multirow{2}{*}{$\begin{array}{l}\mathrm{PM}_{5} \\
\text { P. Rico } \\
\text { X/Al }\end{array}$} & \multirow{2}{*}{$\begin{array}{l}\mathrm{PM}_{1} \\
\text { C. Verde } \\
\text { X/Al }\end{array}$} \\
\hline & X/Al & $r^{2}$ & X/Al & $r^{2}$ & $\mathrm{X} / \mathrm{Al}$ & $r^{2}$ & & & & \\
\hline$\mu \mathrm{g} / \mu \mathrm{g}$ & & & & & & & & & & \\
\hline & & & & & & & 2.14 & 2.70 & 2.13 & 2.18 \\
\hline $\mathrm{Fe}$ & 0.54 & 0.99 & 0.52 & 0.99 & 0.52 & 0.99 & 0.58 & 0.59 & 0.30 & 0.53 \\
\hline K & 0.23 & 0.98 & 0.21 & 0.96 & 0.23 & 0.96 & 0.20 & 0.20 & 0.17 & 0.21 \\
\hline $\mathrm{Mg}$ & 0.17 & 0.85 & 0.19 & 0.94 & 0.20 & 0.95 & & 0.14 & 0.12 & \\
\hline $\mathrm{Ca}$ & 0.47 & 0.85 & 0.51 & 0.75 & 0.42 & 0.79 & 0.28 & 0.40 & 0.38 & 0.35 \\
\hline $\mathrm{Na}$ & 0.16 & 0.76 & 0.16 & 0.28 & 0.18 & 0.47 & & 0.05 & & \\
\hline $\mathrm{NO}_{3}^{-}$ & 0.18 & 0.57 & 0.23 & 0.56 & 0.26 & 0.33 & & & & \\
\hline $\mathrm{SO}_{4}=$ & 0.35 & 0.56 & 0.50 & 0.79 & 0.91 & 0.58 & & & 0.63 & \\
\hline $\mathrm{Cl}^{-}$ & 0.11 & 0.56 & 0.16 & 0.37 & 0.16 & 0.11 & & & & \\
\hline $\mathrm{NH}_{4}^{+}$ & 0.04 & 0.15 & 0.06 & 0.13 & 0.17 & 0.09 & & & & \\
\hline $\mathrm{ng} / \mu \mathrm{g}$ & & & & & & & & & & \\
\hline $\mathrm{La}$ & 0.51 & 0.98 & 0.49 & 0.97 & 0.51 & 0.88 & & & & \\
\hline $\mathrm{Ti}$ & 65.93 & 0.93 & 58.01 & 0.99 & 57.32 & 0.97 & & 80.00 & 44.68 & \\
\hline $\mathrm{P}$ & 12.49 & 0.92 & 11.59 & 0.92 & 12.70 & 0.90 & & 12.00 & & \\
\hline V & 1.39 & 0.90 & 1.53 & 0.92 & 1.70 & 0.79 & & & & \\
\hline $\mathrm{Mn}$ & 9.27 & 0.90 & 9.16 & 0.99 & 8.78 & 0.95 & & & 5.74 & \\
\hline $\mathrm{Sr}$ & 4.05 & 0.90 & 3.93 & 0.86 & 4.00 & 0.88 & & & & \\
\hline $\mathrm{Co}$ & 0.21 & 0.89 & 0.24 & 0.90 & 0.29 & 0.44 & & & 1.06 & \\
\hline $\mathrm{Cr}$ & 1.38 & 0.82 & 2.23 & 0.13 & 2.63 & 0.09 & & & 0.85 & \\
\hline As & 0.16 & 0.81 & 0.16 & 0.86 & 0.24 & 0.59 & & & & \\
\hline $\mathrm{Pb}$ & 0.57 & 0.76 & 0.95 & 0.28 & 1.58 & 0.28 & & & & \\
\hline $\mathrm{Ni}$ & 0.66 & 0.73 & 0.78 & 0.26 & 1.08 & 0.25 & & & & \\
\hline
\end{tabular}

size fractions (slopes $>1$ ). This indicates that, in addition to ammonium-sulphate, other $\mathrm{SO}_{4}^{=}$salts are present in the Izaña samples (e.g. calcium, magnesium or sodium sulphate). The $\mathrm{SO}_{4}^{=}$vs. $\mathrm{NH}_{4}^{+}$dots close to the $1: 1$ line represent samples in which sulphate is predominantly present as ammoniumsulphate (AS). Dots above this line indicate the presence of non-ammonium sulphate (NAS) salts. The distribution of $\mathrm{SO}_{4}^{=}$between AS and NAS species was estimated (Table $4 \mathrm{~b}$ ). Sulphate in the clean free troposphere is predominantly present as AS $(\sim 70 \%)$. However, this AS salt only accounts for about $20-36 \%$ of $\mathrm{SO}_{4}^{=}$in TSP, for $28-30 \%$ of $\mathrm{SO}_{4}^{=}$in $\mathrm{PM}_{10}$ and for $37-56 \% \mathrm{SO}_{4}^{=}$in $\mathrm{PM}_{2.5}$ during dust events. Due to the poor correlation between $\mathrm{NO}_{3}^{-}$and $\mathrm{NH}_{4}^{+}$ in the Izaña samples (not shown for the sake of brevity) and because ammonium-nitrate is typically formed under conditions not recorded at Izaña or in the Saharan airflows (low temperature and/or high relative humidity conditions; Schaap et al., 2002), we do not consider there to be a significant presence of ammonium-nitrate. The presence of nitrate is attributed to Ca-nitrate formation in the dust air masses ( $\mathrm{Li}$ and Shao, 2009).

\subsection{Particle size distribution}

Table 5 shows the mass size distribution of the studied elements and compounds among three fractions: fine $(<2.5 \mu \mathrm{m})$, coarse $(2.5-10 \mu \mathrm{m})$ and super-coarse $(>10 \mu \mathrm{m})$. As expected, most of the elements typically associated with soil dust mostly occur in the coarse and super-coarse ranges. For example, only $16 \%$ of most of major (Al, Fe, K, Ca) and trace ( $\mathrm{La}, \mathrm{Ti}, \mathrm{P}, \mathrm{V}, \mathrm{Mn}, \mathrm{Sr}$, Co and Cr) elements occurred in the fine fraction. In contrast, most of ammonium (77\%) and about half of sulphate $(53 \%)$ occurred in the fine mode. For this reason the relative amount (\%) of sulphate present as AS is higher in $\mathrm{PM}_{2.5}$ than in $\mathrm{PM}_{10}$ and TSP. As averaged during the dust events, the amount of sulphate present as AS accounted for $24 \%$ of total $\mathrm{SO}_{4}^{=}$in TSP, for $27 \%$ of $\mathrm{SO}_{4}^{=}$ in $\mathrm{PM}_{10}$ and for $40 \%$ of $\mathrm{SO}_{4}^{=}$in $\mathrm{PM}_{2.5}$. The presence of nitrate in the coarse mode and of sulphate in the coarse and super-coarse modes is attributed to $\mathrm{Ca}$ and to $\mathrm{Ca}, \mathrm{Na}$ and $\mathrm{Mg}$ bearing salts, respectively (Reid et al., 2003; Kandler et al., 2007; Li and Shao 2009; Dall'Osto et al., 2010). 

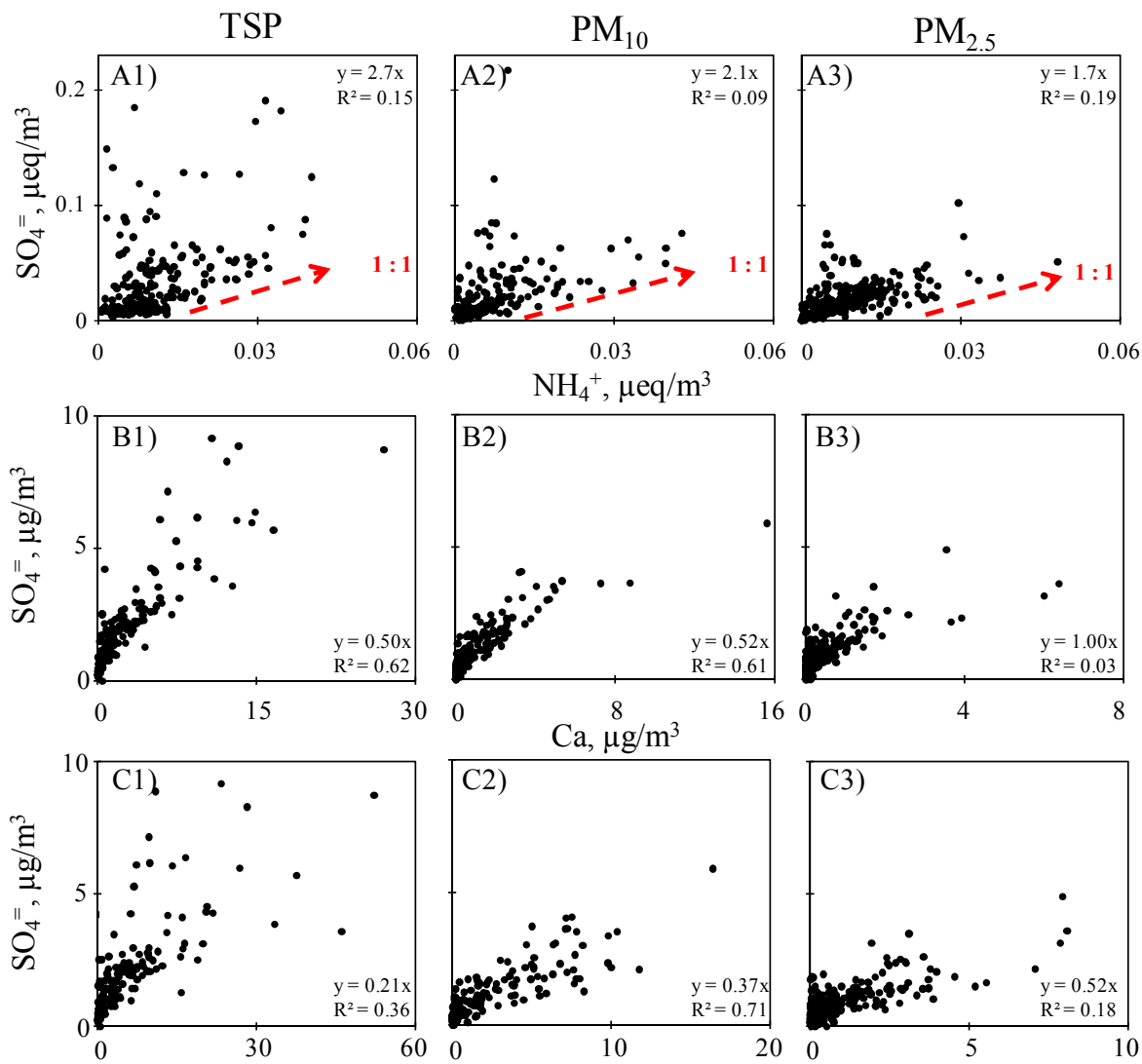

$\mathrm{Al}, \mu \mathrm{g} / \mathrm{m}^{3}$

Fig. 4. Concentrations of sulphate versus ammonium, calcium and aluminium.

Table 4. (A) Mean composition of TSP, $\mathrm{PM}_{10}$ and $\mathrm{PM}_{2.5}$ averaged in three intervals of PM levels: 1th-10th, 55th-80th and 85th-99th. (B) amount of sulphate present as ammonium-sulphate (AS: $\left.\left(\mathrm{NH}_{4}\right)_{2} \mathrm{SO}_{4}\right)$ and as non-ammonium-sulphate (NAS), expressed in $\mu \mathrm{g} \mathrm{m}^{-3}$ and in $\%$ with respect the total of sulphate. Und: undetermined (difference between bulk PMx concentrations and the difference of the sum of the determined compounds). $\Sigma$ : sum of the determined chemical compounds. Al: range of aluminium concentrations $\left(\mu \mathrm{g} \mathrm{m}^{-3}\right)$.

\begin{tabular}{|c|c|c|c|c|c|c|c|c|c|c|c|c|c|c|c|c|c|c|}
\hline \multirow{3}{*}{$\begin{array}{l}\mathrm{Al}: \\
\mathrm{N} \\
\end{array}$} & \multicolumn{6}{|c|}{ TSP } & \multicolumn{6}{|c|}{$\mathrm{PM}_{10}$} & \multicolumn{6}{|c|}{$\mathrm{PM}_{2.5}$} \\
\hline & \multicolumn{2}{|c|}{$\begin{array}{c}1 \text { th- } 10 \text { th } \\
0.0-0.2\end{array}$} & \multicolumn{2}{|c|}{$\begin{array}{l}\text { 55th-80th } \\
2.0-7.5\end{array}$} & \multicolumn{2}{|c|}{$\begin{array}{c}\text { 85th-99th } \\
9.7-38.2\end{array}$} & \multicolumn{2}{|c|}{$\begin{array}{c}1 \text { th-10th } \\
0.0-0.0\end{array}$} & \multicolumn{2}{|c|}{$\begin{array}{c}55 \text { th-80th } \\
0.6-3.9\end{array}$} & \multicolumn{2}{|c|}{$\begin{array}{l}\text { 85th-99th } \\
5.1-11.7\end{array}$} & \multicolumn{2}{|c|}{$\begin{array}{c}1 \text { th-10th } \\
0.0-0.0\end{array}$} & \multicolumn{2}{|c|}{$\begin{array}{c}55 \text { th-80th } \\
0.4-1.5\end{array}$} & \multicolumn{2}{|c|}{$\begin{array}{c}\text { 85th-99th } \\
2.0-7.9\end{array}$} \\
\hline & 23 & & 51 & & 27 & & 22 & & 51 & & 28 & & 31 & & 69 & & 39 & \\
\hline (A) & $\mu \mathrm{g} \mathrm{m}^{-3}$ & $\%$ & $\mu \mathrm{g} \mathrm{m}^{-3}$ & $\%$ & $\mu \mathrm{g} \mathrm{m}^{-3}$ & $\%$ & $\mu \mathrm{g} \mathrm{m}^{-3}$ & $\%$ & $\mu \mathrm{g} \mathrm{m}^{-3}$ & $\%$ & $\mu \mathrm{g} \mathrm{m}^{-3}$ & $\%$ & $\mu \mathrm{g} \mathrm{m}^{-3}$ & $\%$ & $\mu \mathrm{g} \mathrm{m}^{-3}$ & $\%$ & $\mu \mathrm{g} \mathrm{m}^{-3}$ & $\%$ \\
\hline PM & 4.94 & & 62.96 & & 217.67 & & 2.96 & & 29.29 & & 100.87 & & 3.30 & & 15.03 & & 42.64 & \\
\hline und & 1.05 & & 14.53 & & 43.53 & & 0.59 & & 5.28 & & 23.28 & & 0.58 & & 2.26 & & 4.59 & \\
\hline$\sum$ & 3.89 & 78.7 & 48.43 & 76.9 & 174.14 & 80.0 & 2.37 & 80.0 & 24.01 & 82.0 & 77.59 & 76.9 & 2.72 & 82.3 & 12.77 & 84.9 & 38.05 & 89.2 \\
\hline $\mathrm{NO}_{3}^{-}$ & 0.08 & 1.6 & 1.23 & 2.0 & 2.10 & 1.0 & 0.09 & 2.9 & 0.61 & 2.1 & 1.18 & 1.2 & 0.10 & 3.0 & 0.27 & 1.8 & 0.53 & 1.2 \\
\hline $\mathrm{NH}_{4}^{+}$ & 0.13 & 2.6 & 0.26 & 0.4 & 0.29 & 0.1 & 0.06 & 2.1 & 0.13 & 0.5 & 0.26 & 0.3 & 0.10 & 3.0 & 0.18 & 1.2 & 0.24 & 0.6 \\
\hline $\mathrm{OM}+\mathrm{EC}$ & 1.86 & 37.7 & 3.27 & 5.2 & 5.40 & 2.5 & 1.57 & 53.1 & 2.88 & 9.8 & 3.81 & 3.8 & 1.88 & 57.0 & 3.10 & 20.6 & 3.35 & 7.8 \\
\hline (B) $\mathrm{SO}_{4}^{=}$ & $\mu \mathrm{g} \mathrm{m}^{-3}$ & $\%$ & $\mu \mathrm{g} \mathrm{m}^{-3}$ & $\%$ & $\mu \mathrm{g} \mathrm{m}^{-3}$ & $\%$ & $\mu \mathrm{g} \mathrm{m}^{-3}$ & $\%$ & $\mu \mathrm{g} \mathrm{m}^{-3}$ & $\%$ & $\mu \mathrm{g} \mathrm{m}^{-3}$ & $\%$ & $\mu \mathrm{g} \mathrm{m}^{-3}$ & $\%$ & $\mu \mathrm{g} \mathrm{m}^{-3}$ & $\%$ & $\mu \mathrm{g} \mathrm{m}^{-3}$ & $\%$ \\
\hline as AS & 0.35 & 77 & 0.69 & 36 & 0.77 & 18 & 0.16 & 62 & 0.35 & 30 & 0.69 & 29 & 0.27 & 68 & 0.48 & 56 & 0.64 & 37 \\
\hline as NAS & 0.10 & 23 & 1.26 & 64 & 3.51 & 82 & 0.10 & 38 & 0.80 & 70 & 1.73 & 71 & 0.12 & 32 & 0.38 & 44 & 1.10 & 63 \\
\hline
\end{tabular}


Table 5. Mass size distribution (\%) of PMx components at Izaña.

\begin{tabular}{lrrr}
\hline & $\begin{array}{r}\text { Fine } \\
<2.5 \mu \mathrm{m}\end{array}$ & $\begin{array}{r}\text { Coarse } \\
2.5-10 \mu \mathrm{m}\end{array}$ & $\begin{array}{r}\text { Supercoarse } \\
>10 \mu \mathrm{m}\end{array}$ \\
\hline $\mathrm{PM}$ & 0.19 & 0.31 & 0.50 \\
$\mathrm{Al}$ & 0.16 & 0.46 & 0.38 \\
$\mathrm{Fe}$ & 0.17 & 0.37 & 0.47 \\
$\mathrm{~K}$ & 0.15 & 0.37 & 0.48 \\
$\mathrm{Mg}$ & 0.17 & 0.42 & 0.42 \\
$\mathrm{Ca}$ & 0.14 & 0.36 & 0.50 \\
$\mathrm{Na}$ & 0.12 & 0.23 & 0.65 \\
$\mathrm{Cl}$ & 0.04 & 0.32 & 0.63 \\
$\mathrm{SO}=$ & 0.53 & 0.27 & 0.20 \\
$\mathrm{NO}$ & 0.20 & 0.71 & 0.10 \\
$\mathrm{NH}$ & 0.77 & 0.13 & 0.10 \\
$\mathrm{La}$ & 0.17 & 0.42 & 0.41 \\
$\mathrm{Ti}$ & 0.17 & 0.28 & 0.54 \\
$\mathrm{P}$ & 0.18 & 0.30 & 0.52 \\
$\mathrm{~V}$ & 0.18 & 0.37 & 0.46 \\
$\mathrm{Mn}$ & 0.17 & 0.31 & 0.52 \\
$\mathrm{Sr}$ & 0.16 & 0.25 & 0.59 \\
$\mathrm{Co}$ & 0.17 & 0.41 & 0.42 \\
$\mathrm{Cr}$ & 0.17 & 0.32 & 0.50 \\
$\mathrm{As}$ & 0.27 & 0.39 & 0.34 \\
$\mathrm{~Pb}$ & 0.29 & 0.38 & 0.33 \\
$\mathrm{Ni}$ & 0.23 & 0.20 & 0.57 \\
\hline & & &
\end{tabular}

The peculiar features of sulphate at Izaña (a significant fraction in the coarse and supercoarse fractions, and a low proportion of ammonium sulphate) contrast with those observed in Europe, where this salt is predominantly present as ammonium-sulphate in the fine fraction (Rodríguez et al., 2007).

Figure 5 shows the averaged volume size distribution measured during dust episodes. Two modes are clearly observed, centered at $240 \mathrm{~nm}$ and $3.0 \mu \mathrm{m}$. The fine mode is attributed to the presence of ammonium sulphate, whereas the coarse mode is predominantly due to dust. This size distribution and the features of sulphate and nitrate described above, suggests that both external (ammonium-sulphate in the fine fraction and dust in the coarse fraction) and internal (dust coated by sulphate in the coarse mode) aerosol mixing may occur in the SAL. The coarse mode of this size distribution is similar to that observed by Maring et al. (2003) within the Saharan Air Layer in campaigns performed at Izaña and Puerto Rico.

\subsection{Source region and transport pathways}

In order to focus our attention on the SAL, only events with dust concentrations $>10 \mu \mathrm{g} \mathrm{m}^{-3}$ in $\mathrm{PM}_{10}$ were studied. Thus, a total of 44 dust episodes were used for determining the MCAR plots (Figs. 8, 10 and 14). These events mostly occured from July to September (Fig. 6a).

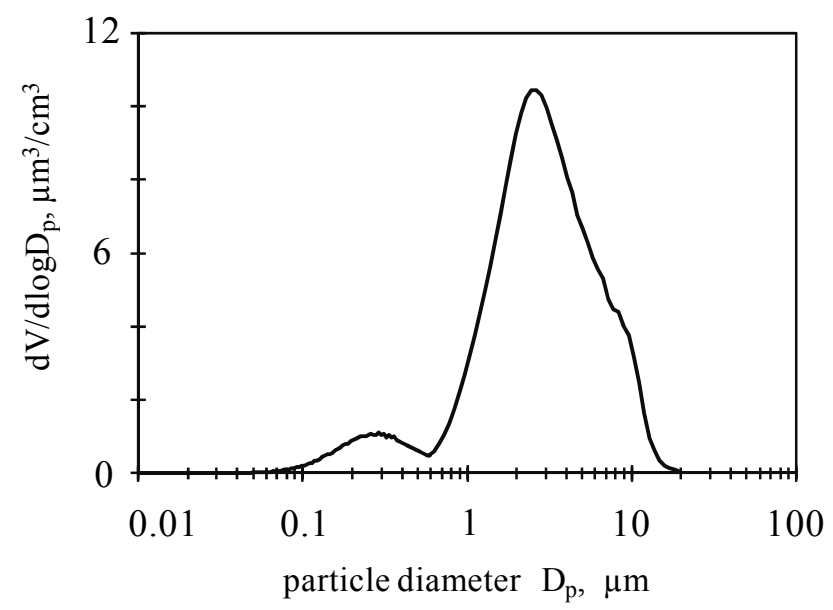

Fig. 5. Particle size distribution recorded at Izaña during Saharan dust events.

\subsubsection{Transport pathways of Saharan airflows}

The frequency with which air masses passed over each $1^{\circ} \times 1^{\circ}$ pixel included in the MCAR plot is shown in Fig. $6 \mathrm{~b}$. The region of high frequency ( $\geq 50$ counts) reveals that there is a well defined transport pathway (red arrow in Fig. 6b): air originally from the Mediterranean flows north to south across Tunisia and Northern Algeria and is then westward transported along the southern slope of the Atlas mountains toward the North Atlantic Ocean. This transport pathway is similar to the "mean airflows" previously described by Millán et al. (1997) and Gangoiti et al. (2006). This transport pathway is the result of the meteorological scenario typical of the summertime (Fig. 7), which will be discussed below. In the frequency plot shown in Fig. 6c, the frequency scale has been cut to 100 in order to highlight regions of a relatively lower frequency. It can be observed how air from other regions out of the main transport pathway may also be transported to Izaña and mixed with the SAL.

\subsubsection{Aluminum}

The objective of this section is to identify the location of the main sources of the desert dust and to highlight the different geographical distribution with respect to the industrial sources that will be described below. The potential contribution of anthropogenic activities to Al load observed in the SAL will be discussed below (simultaneously with P). A detailed description of the features of the observed soil dust sources is out of the scope of this paper. Figure 8a shows the MCAR plot for Al. High concentrations of $\mathrm{Al}$ are recorded at Izaña when air masses have passed over several well delimited regions:

- Western Algeria: Bechar. A large extension of high Al concentrations is observed (in the MCAR plots) at the 

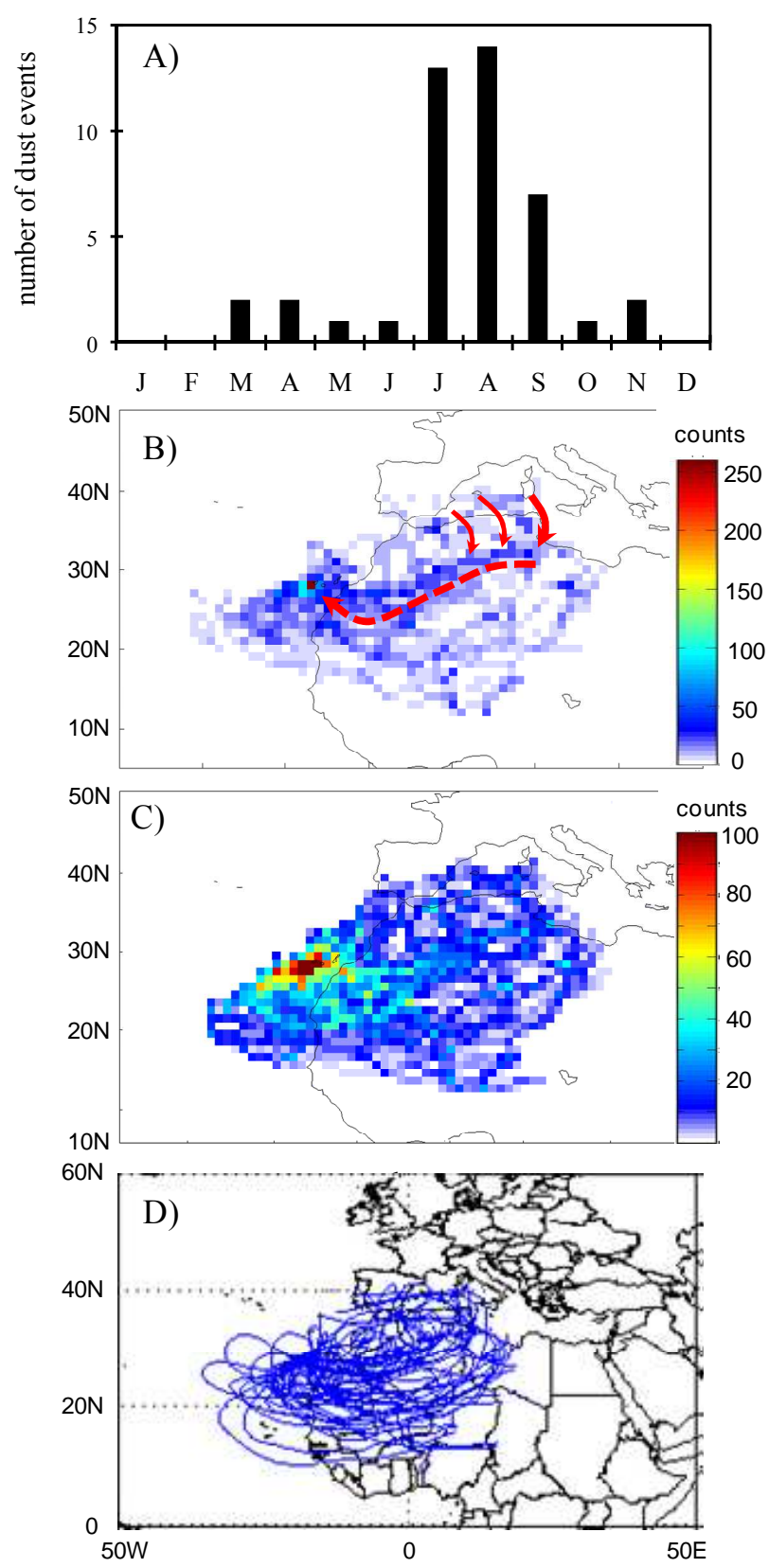

Fig. 6. (A) Number of events with dust concentrations $>10 \mu \mathrm{g} \mathrm{m}^{-3}$ in $\mathrm{PM}_{10}$ analyzed in this study. (B) and (C) Frequency of pass of trajectories by each $1^{\circ} \times 1^{\circ}$ pixel scale set to maximum value (B) and set to 100 (C). (D) Set of trajectories included in the analysis of dust events in $\mathrm{PM}_{10}$. Red line in (A) highlights the deduced transport pathway. Red line in (D) highlights the recirculation process.

south of the southern slope of the Moroccan Atlas, expanding to both sides of the border between Morocco and Algeria. The Algerian part of this region is the socalled Bechar province $\left(7-8 \mu \mathrm{g} \mathrm{m}^{-3}\right.$; centered at about $30.5^{\circ} \mathrm{N}, 3.0^{\circ} \mathrm{W}$; Figs. 2 and $8 \mathrm{a}$ ). Maps and satellite images show a great abundance of dry drainage chan- nels originating from water streams that flowed from the southern slope of the Moroccan Atlas to Bechar. These drainage systems converge in many cases to wadis (the Arabic term traditionally referring to a valley which is a dry riverbed that, in many cases, contains water only during times of heavy rain or simply an intermittent stream). Some of the systems observed are the following: wadi Abadla $\left(31.000^{\circ} \mathrm{N}, 2.700^{\circ} \mathrm{W}\right)$ or wadi Bechar $\left(31.650^{\circ} \mathrm{N}, 2.130^{\circ} \mathrm{E}\right)$. Some of them are illustrated in the map shown in Fig. 2. Many of these wadis and smaller drainage systems conclude in topographic lows where lakes may be formed during floods. Satellite images allow the identification of large extensions of topographic lows with the appearance of dry lake beds, with large amounts of accumulated dust deposits (dry alluvial). Figure 9a shows, as an example, the system located at the south of the Algerian part of the wadi Ouead-Dsoura: the drainage channels and the dust accumulation in the topographic low are clearly observed. In summary, large amounts of dust are accumulated along many drainage systems, wadis and topographic lows of the region (Chorowicz and Fabre, 1997). The intense NNE winds in summer favors dust emissions in this region (Fig. 7a). This is in agreement with the findings of previous studies. Brooks and collaborators observed dust emissions in this region using Infra-red Difference Dust Index (IDDI) maps (Brooks, 2000; Brooks and Legrand, 2000). As a consequence of this and because Bechar is within the main transport pathway (Fig. 6b), this is probably a predominant source of the soil dust sampled at Izaña, representative of the northern side of the summer subtropical SAL.

- Northern Algeria and Tunisia. High concentrations of $\mathrm{Al}$ are observed (in the MCAR plots) in the southern slope of the Saharan Atlas (Fig. 8a), where a great abundance of dry drainage channels originating from water streams that flowed from the Southern Atlas toward southern lowlands are observed in Google Earth ${ }^{\mathrm{TM}}$ (also illustrated in Fig. 2). The highest concentrations of $\mathrm{Al}$ (8-10 $\mu \mathrm{g} \mathrm{m}^{-3}$; Fig. 8a) are observed in a large topographic low that expands from Northeastern Algeria to Tunisia, where an extensive system of salt lakes and dry lakes are found. This region receives an annual direct precipitation $<100 \mathrm{~mm}$, in such a way that salt lakes have only water in the lowest area, with high amount of dust accumulated around the chotts (Prospero et al., 2002; Hamdi-Aissa et al., 2004). The largest dry salt lakes are Chott Melrhir $\left(34.210^{\circ} \mathrm{N}, 6.360^{\circ} \mathrm{E}\right)$ in Algeria and Chott Jerid $\left(33.700^{\circ} \mathrm{N}, 8.400^{\circ} \mathrm{E}\right)$ in Tunisia. The high Aerosol Index values due to dust emissions in summer in this region (Fig. 1a) were previously described by Prospero et al. (2002).

- Eastern Algeria: Ouargla basin. An extensive area of moderate $\mathrm{Al}$ concentrations $\left(6.5-7.5 \mu \mathrm{g} \mathrm{m}^{-3}\right)$ is 

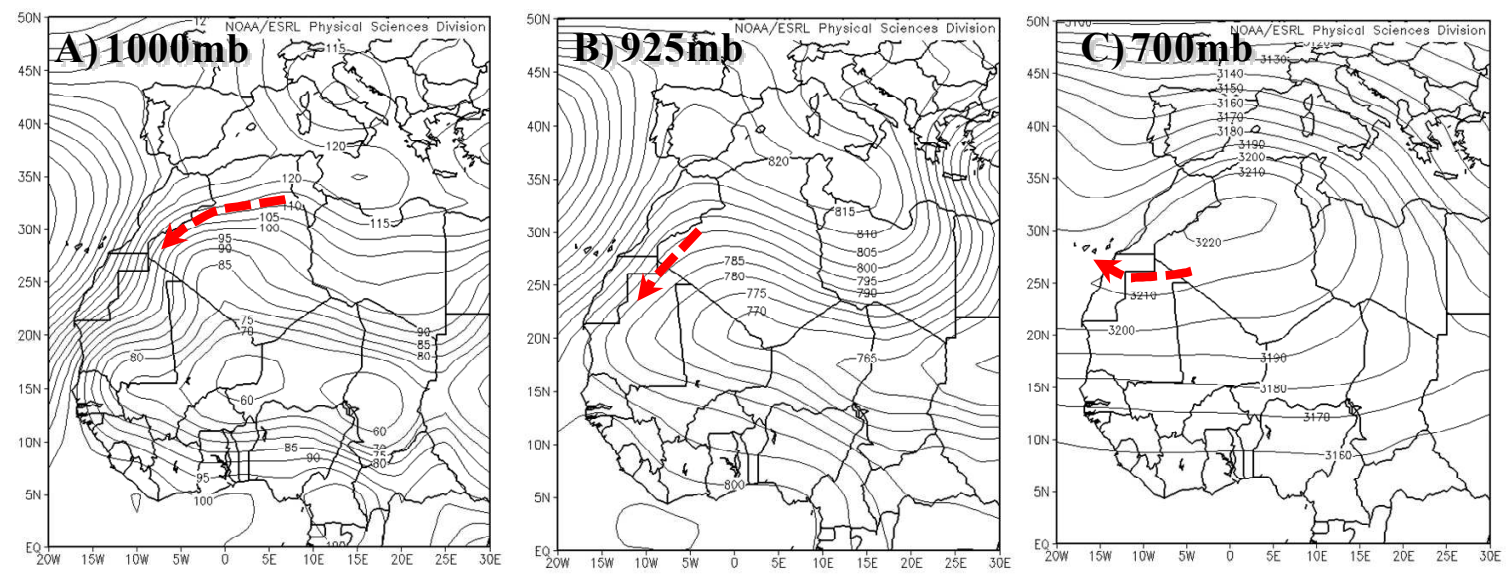

Fig. 7. Geopotential for 1000, 925 and $700 \mathrm{mb}$ averaged during July and August.
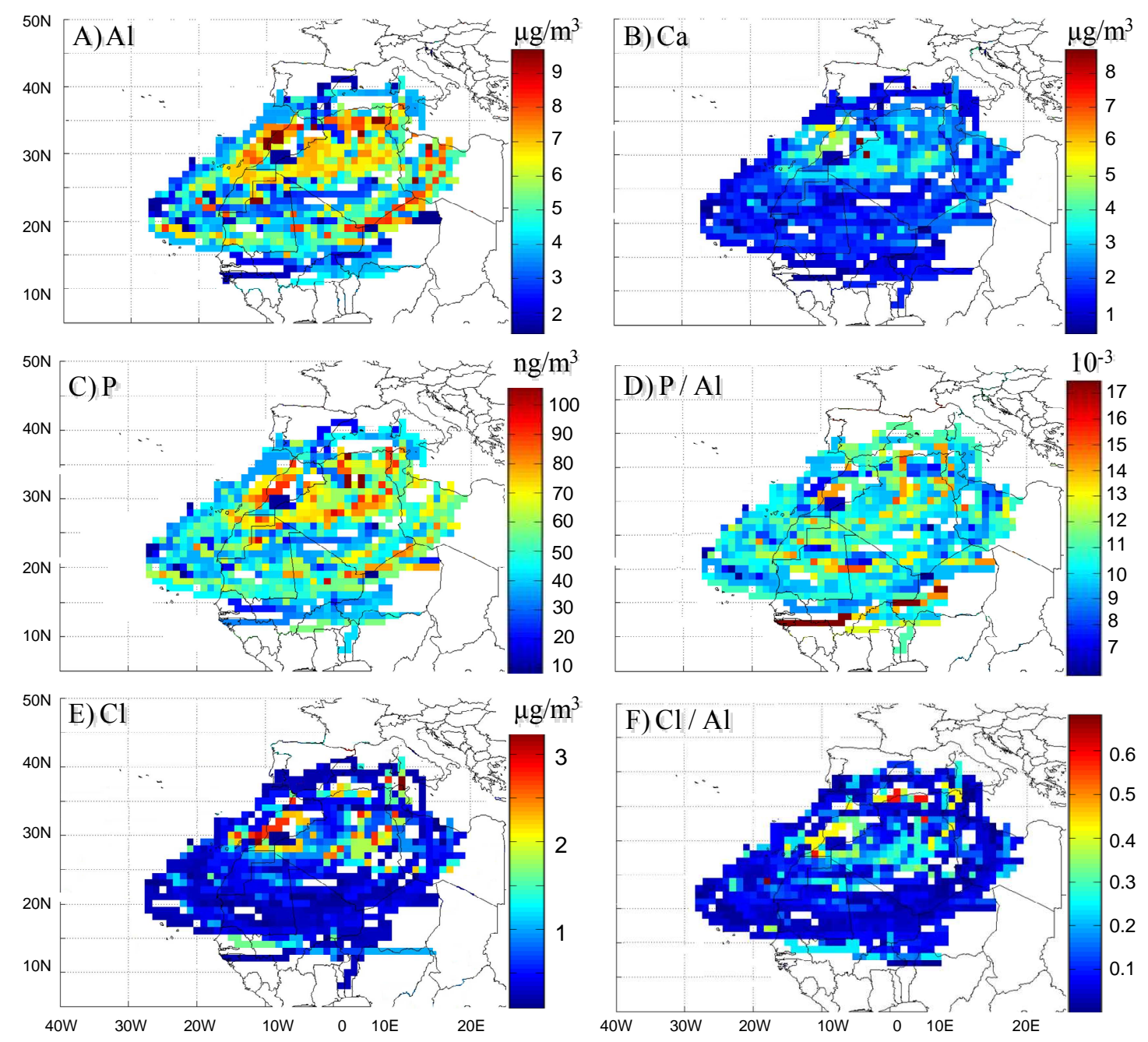

Fig. 8. Median concentrations at receptor (MCAR) plots for $\mathrm{Al}, \mathrm{Ca}, \mathrm{P}$ and $\mathrm{Cl}$ concentrations and for the $\mathrm{P} / \mathrm{Al}$ and $\mathrm{Cl} / \mathrm{Al}$ ratios in the $\mathrm{PM} 10$ fraction. 

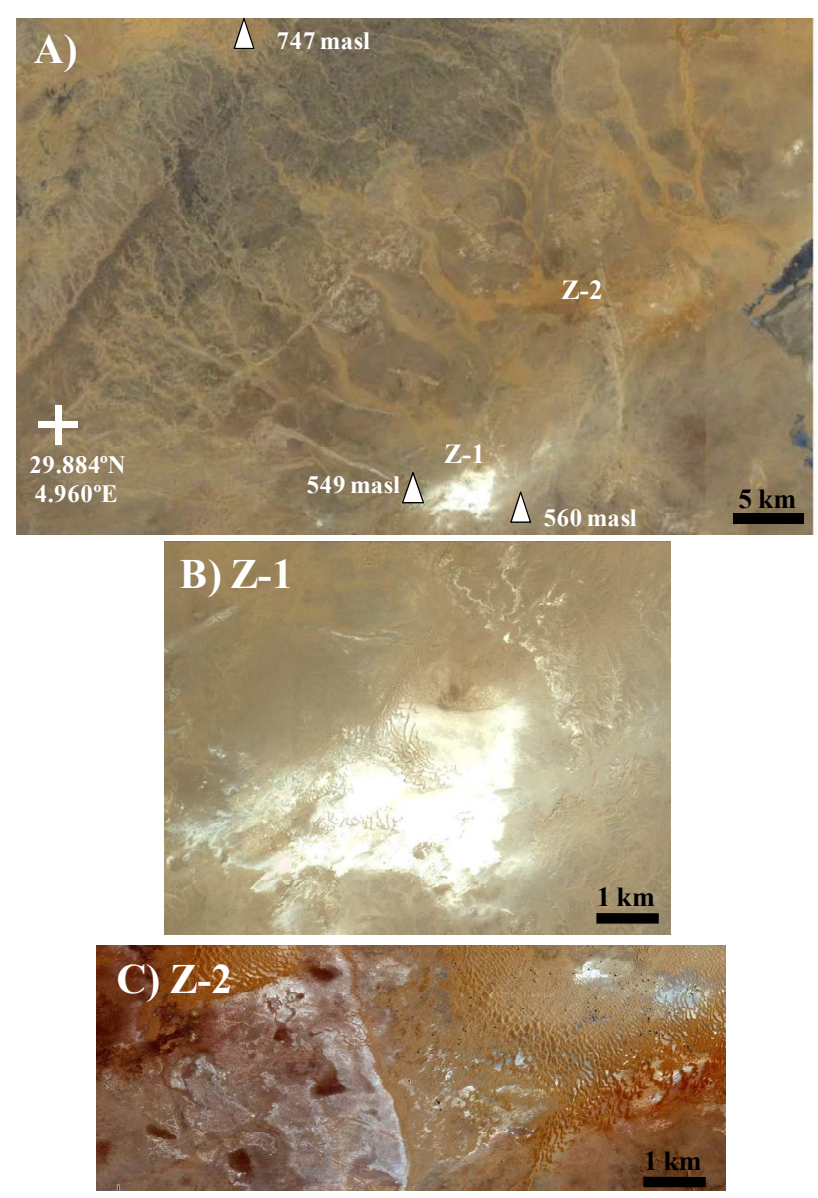

Fig. 9. Satellite view of a part of the Bechar province (A) and two zooms of the area (B and $\mathbf{C})$.

observed along the axis of the Ouargla basin (Figs. 2 and 8a). The axis of this basin exhibits a northnortheastward down slope. The bottom of the axis is placed at about $220 \mathrm{~m}$ a.s.l. on its southern edge $\left(30.48^{\circ} \mathrm{N}, 4.28^{\circ} \mathrm{E}\right.$; wadi Mya, descending from the northern slope of the Tassili-N-Ajjer mountains, located in Central Algeria) and at about 32 meters below sea level on its northern edge (in the Chott Melrhir, $34.210^{\circ} \mathrm{N}, 6.360^{\circ} \mathrm{E}$, Northern Algeria). High concentrations of $\mathrm{Al}\left(7-8 \mu \mathrm{g} \mathrm{m}^{-3}\right)$ are observed just in the southern part of the basin, where wady Mya descends from the Tassili-N-Ajjer mountains. A number of saline lakes (Chotts) lie along the axis of the basin (Fig. 12a; discussed in detail below). High Aerosol Index due to dust emissions along the Ouargla basin were previously described by Prospero et al. (2002). These were attributed to emissions of dust accumulated near the chotts. Observe in Fig. 1a how the shape of the Aerosol Index $>1.5$ spot over Ouargla region is similar to the topographic low of the Ouargla basin (Fig. 2).
Our results clearly indicate that the Southern slope of the Atlas mountain chain (from Tunisia to Morocco) and the Ouargla basin are an important source of the dust advected in summer to the Northern edge of the SAL (Fig. 8a). During the campaign of the Saharan Mineral Dust Experiment (SAMUM) project performed in May-June 2006, Knippertz et al. (2007) described dust emission in the Moroccan side (East) of the Bechar basin. Moreover, it was observed that topographic channeling of air from Tunisia to Central Algeria activates dust emissions in this region (Knippertz et al., 2009). These airflows are in agreement with those we obtained (Figs. $6 \mathrm{~b}$ and $7 \mathrm{a}$ ).

\subsubsection{Calcium}

The MCAR plot for the Ca concentrations recorded at Izaña is shown in Fig. 8b. The strong northward gradient observed in $\mathrm{Ca}$ concentrations is in agreement with previous studies and soil maps (Schütz and Sebert, 1987; Claquin et al., 1999; Desboeufs and Cautenet, 2005; Kandler et al., 2007). These studies argued that this behavior is mainly due to the high content in calcite in the soils of Northern Morocco and Northern Algeria $\left(>27^{\circ} \mathrm{N}\right)$. Hereafter we will discuss the involvement of the content of gypsum and anhydrite minerals in the soil. The potential contribution of anthropogenic activities to Ca load observed in the SAL will be discussed below (with P).

\subsubsection{Nitrate, ammonium and sulphate: role of industrial emissions}

Figure 10 shows the MCAR plots for $\mathrm{NO}_{3}^{-}, \mathrm{NH}_{4}^{+}$and $\mathrm{SO}_{4}^{=}$. The amount of sulphate present as ammonium sulphate (AS) is shown in the MCAR plots of Fig. 14a and c. High concentrations of these aerosol components $\left(\mathrm{NO}_{3}^{-}, \mathrm{NH}_{4}^{+}\right.$and $\left.\mathrm{SO}_{4}^{=}\right)$ are recorded when air arriving to Izaña have flown over the Atlantic coast of Morocco, Eastern Algeria and Northern Algeria and Tunisia. The following industrial estates, emission sources of gaseous precursors $\left(\mathrm{SO}_{\mathrm{x}}, \mathrm{NO}_{\mathrm{x}}\right.$ and $\left.\mathrm{NH}_{3}\right)$ of these aerosol compounds, have been indentified in these regions:

- Morocco. A region of high concentrations of nitrate, sulphate and ammonium $(2.0-2.2, \sim 0.12$ and 3.0$3.5 \mu \mathrm{g} \mathrm{m}^{-3}$, respectively) is observed (in the MCAR plots) parallel to the Atlantic coast of the country. The following industrial estates are placed, north to south, in this region (Fig. 2, Table 1):

- Sidi Kassem $\left(34.233^{\circ}\right.$ N, $\left.5.718^{\circ} \mathrm{W}\right)$, a crude oil refinery with about $\sim 30000$ barrels per day (bpd) production, located in the northern edge of the corridor,

- Great Casablanca area, where Mohammedia crude oil refinery $\left(33.686^{\circ} \mathrm{N}, 7.426^{\circ} \mathrm{W} ; \sim 125000 \mathrm{bpd}\right)$ and several power stations are located. Available emission inventory (dating from the early 

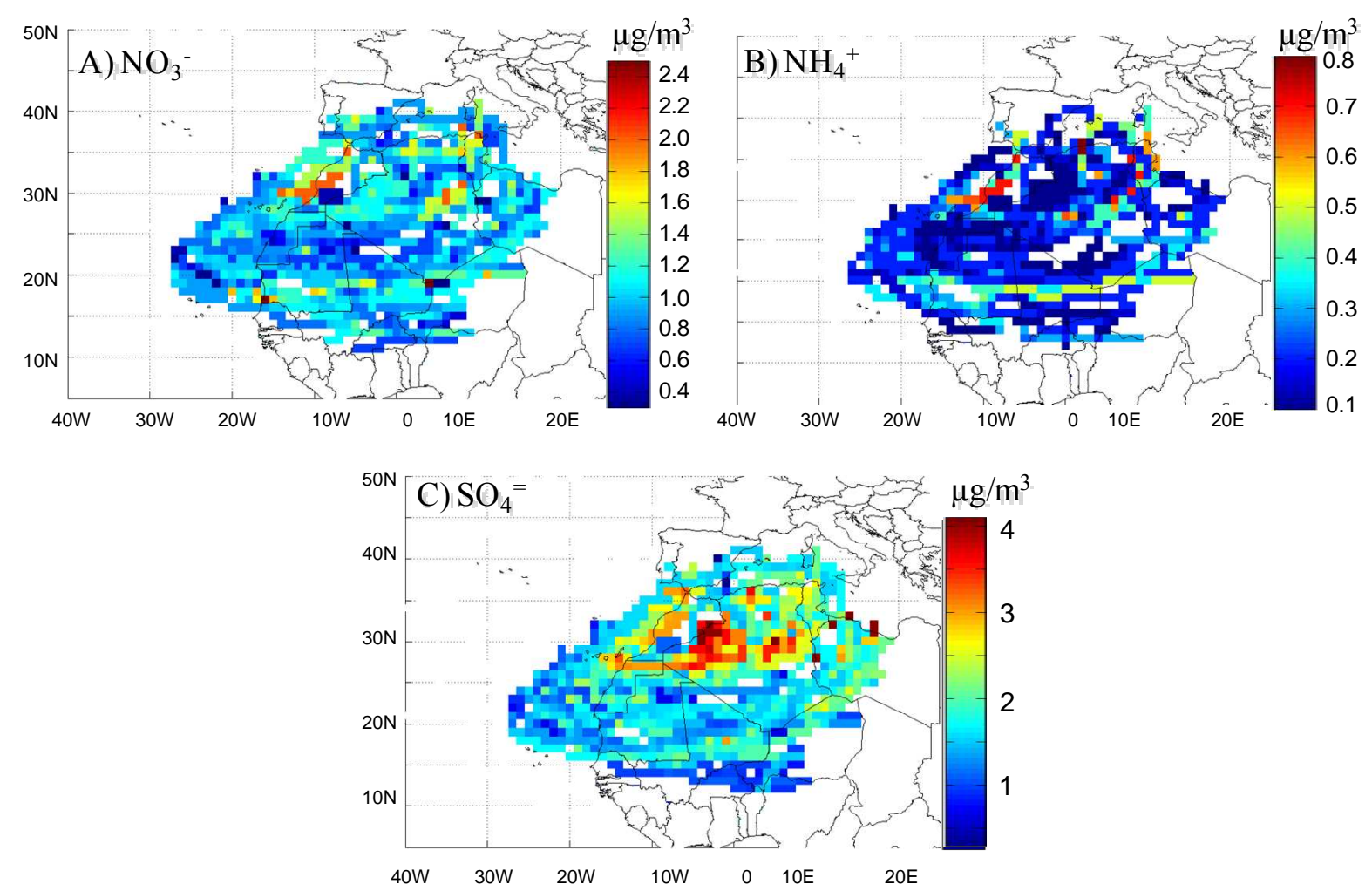

Fig. 10. Median concentrations at receptor (MCAR) plots for nitrate, ammonium and sulphate concentrations in the $\mathrm{PM}_{10}$ fraction.

1990s) estimated annual $\mathrm{SO}_{2}$ and $\mathrm{NO}_{\mathrm{x}}$ emissions of about 94600 and 14800 tons $\mathrm{yr}^{-1}$, respectively (Khatami et al., 1998). About half of these $\mathrm{SO}_{2}$ and $\mathrm{NO}_{\mathrm{x}}$ emissions were attributed to Mohammedia coal fired power station $\left(33.682^{\circ} \mathrm{N}, 7.434^{\circ} \mathrm{W}\right.$; $600 \mathrm{Mw})$,

- Jorf Lasfar, where the largest coal fired power station of the country is placed $\left(33.105^{\circ} \mathrm{N}, 8.637^{\circ} \mathrm{W}\right.$; $1400 \mathrm{Mw}$ ),

- Jorf Lasfer $\left(33.111^{\circ} \mathrm{N}, 8.606^{\circ} \mathrm{W}\right)$ and Safi $\left(32.222^{\circ} \mathrm{N}, 9.249^{\circ} \mathrm{W}\right)$, where two large chemical plants that produce phosphoric acid and ammonium phosphate (as part of fertilizer industry) are placed. Figure 11a and $\mathrm{b}$ shows a picture of Safi plant. Below it will be described how these emissions are a source of sulphate, ammonium, nitrate and other particulate pollutants in the region (CNEDD Report, 2007; Gaudry et al., 2007; Erramli et al., 2008).

Airborne particle number size distribution measurements performed (during SAMUM project) from the south of Moroccan Atlas (Eastern Bechar basin) to Casablanca coast, showed that the number of particles smaller than $<500 \mathrm{~nm}$ was much higher at the north of the Atlas; moreover samples collected during these flights showed the presence of
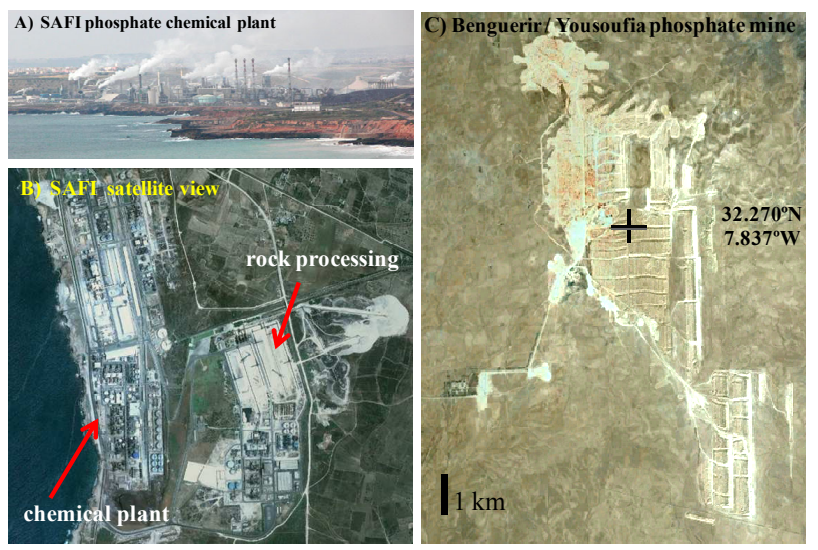

Fig. 11. Pictures of SAFI phosphate/fertilizer industry (A, B) and Benguerir/Yousoufia phosphate mine (C) in Morocco.

ammonium-sulphate particles of $350 \mathrm{~nm}$ size (Weinzierl et al., 2009). The size distribution (Fig. 5) and the MCAR plot for ammonium sulphate (Figs. 10b, c and 14a) we have obtained accounts for these observations.

- Eastern Algeria. High concentrations of nitrate, sulphate and ammonium (1.5-2.0, 2.5-3.5 and 0.3$0.6 \mu \mathrm{g} \mathrm{m}^{-3}$, respectively) are observed in Ouargla 
region. This area is centered over Hassi Messahoud $\left(31.670^{\circ} \mathrm{N}, 6.070^{\circ} \mathrm{E}\right)$, where one of the largest oil extraction fields in Africa and two crude oil refineries $(30000 \mathrm{bpd})$ are placed. The plumes of these emissions around this city can be observed by the links available in Google Earth ${ }^{\mathrm{TM}}$ to Panoramio ${ }^{\mathrm{TM}}$; examples in Fig. 2c-d. The air quality impairment in the region due to these emissions is well documented (Yassaa et al., 2001a; Yassaa and Cecinato, 2005).

- Northern Algeria and Tunisia. High nitrate, sulphate and ammonium concentrations are also observed in the coast of Algeria and Tunisia, in the Mediterranean, where the following industrial facilities are placed (Figs. 2 and 10 and Table 1):

- Arzew $\left(35.811^{\circ} \mathrm{N}, 0.265^{\circ} \mathrm{W}\right)$ crude oil refinery (60 000 bpd),

- Algier $\left(36.760^{\circ} \mathrm{N}, 3.066^{\circ} \mathrm{E}\right)$ crude oil refinery (60 000 bpd; Yassaa et al., 2001b),

- Skikda $\left(36.879^{\circ} \mathrm{N}, 6.945^{\circ} \mathrm{E}\right)$ crude oil refinery (300 000 bpd),

- Annaba $\left(36.871^{\circ} \mathrm{N}, 7.765^{\circ} \mathrm{E}\right)$ petrochemical plant for the production of sulphuric acid, phosphoric acid and diamonium phosphate,

- Bizerte $\left(36.800^{\circ} \mathrm{N}, 10.290^{\circ} \mathrm{E}\right)$ crude refinery (35000 bpd),

- Rades $\left(36.799^{\circ} \mathrm{N}, 10.286^{\circ} \mathrm{E}\right)$ power plant,

The air quality impairment due to the industrial emissions in these regions is a well known fact (e.g. Yasaa et al., 2001b; Ali-Khodja et al., 1998, 2008; Tlili et al., 2007).

\subsubsection{Phosphorus}

Relatively high phosphorous concentrations are observed (in the MCAR plots) in the Bechar basin (70-80 $\mathrm{ng} \mathrm{m}^{-3}$; Fig. 8c), where important soil dust emissions occur. Because this region is within the main transport pathway, this is probably the most frequent source of the soil P sampled at Izaña (as in the case of $\mathrm{Al}$ discussed above). A remarkable feature is that the highest concentrations of $\mathrm{P}$ are observed in well defined regions where mining and industrial emissions occur: Morocco, a "Tunisia - Eastern Algeria" SW-ward corridor and the southern slope of the Saharan Atlas (Algeria).

- Morocco. High concentrations of P (80-100 $\mathrm{ng} \mathrm{m}^{-3}$ ) are observed in a NE to SW corridor expanding along the country (Fig. 8c). As noted above, high nitrate, ammonium and sulphate concentrations $(2.0-2.2, \sim 0.12$, $3.0-3.5 \mathrm{\mu g} \mathrm{m}^{-3}$, respectively) are also observed along this corridor (Fig. 10). The high concentrations of phosphorus and chlorine observed along this corridor (Fig. 8c and e) supports the involvement of the above cited phosphate industry; e.g. that located in Safi $\left(32.222^{\circ} \mathrm{N}, 9.249^{\circ} \mathrm{W}\right.$; Figs. 2, 11a and b) and Jorf Lasfer $\left(33.111^{\circ} \mathrm{N}, 8.606^{\circ} \mathrm{W}\right.$; Fig. 2). Morocco is the second largest phosphate producer in the world, with an annual production of about 23 million tons $\mathrm{yr}^{-1}$. The main phosphate mines are placed in Khouribga $\left(32.662^{\circ} \mathrm{N}\right.$, $\left.6.703^{\circ} \mathrm{W}\right)$, Benguerir/Yousoufia $\left(32.270^{\circ} \mathrm{N}, 7.837^{\circ} \mathrm{W}\right)$ and Meskala (31.366 ${ }^{\circ}$ N, $9.477^{\circ} \mathrm{W}$; Fig. 2 and Table 1). Phosphate rock extractions also occur at Bou Craa in Western Sahara $\left(26.313^{\circ} \mathrm{N}, 12.846^{\circ} \mathrm{W}\right)$. About half of ores are transformed in the above cited plants. Observe in Fig. 8c-f and Fig. 10 how high concentrations of $\mathrm{P}$, $\mathrm{P} / \mathrm{Al}, \mathrm{Cl} / \mathrm{Cl} / \mathrm{P}, \mathrm{NO}_{3}^{-}, \mathrm{SO}_{4}^{=}$and $\mathrm{NH}_{4}^{+}$are observed in the region where the Moroccan industry and mines of phosphates are located. The emissions may occur in the mines and/or during the industrial processing (depending on the pollutant). In the mines, emissions of $\mathrm{P}$ containing particles may occur during the extraction process or due to the action of wind on the soil of the open mines. The change in the use of soil and soil texture due to the mining activities may increase dust emissions in the region (Zender et al., 2004). This accounts for the high concentrations of $\mathrm{Al}$ and $\mathrm{Ca}$ observed in this region of Morocco (MCAR plots in Fig. 8a-b). See an example of these mines, Benguerir/Yousoufia, in Fig. 11c. The emissions links to the industrial processing of the rock are more complex. The industrial production of phosphoric acid results from the reaction between sulphuric acid and phosphate ores. During the reaction, insoluble calcium sulphate (so called phosphogypsum) is produced. This industry results in the emissions of aerosol gaseous precursors, such as ammonia $\left(\mathrm{NH}_{3}\right)$, sulfur oxides $\left(\mathrm{SO}_{\mathrm{x}} / \mathrm{SO}_{2}\right)$, inorganic chlorine compounds (e.g. $\mathrm{HCl}$ and $\mathrm{KCl}$ ), and in the emissions of primary mineral particles (e.g. calcium-sulphate and phosphate). The high ratios of $\mathrm{P} / \mathrm{Al}$ and $\mathrm{Cl} / \mathrm{Al}$ over the Moroccan corridor indicate enrichment in phosphorous and chloride of the dust particles in the region (Fig. 8cf). The observed high $\mathrm{Ca}, \mathrm{SO}_{4}^{=}$and $\mathrm{P}$ concentrations agree with the main emissions of the region (Figs. 8 and 10). The pollution in the air, water and soils of this region of Morocco due to these industrial activities is well documented (CNEDD Report, 2007; Gaudry et al., 2007; Erramli et al., 2008). The prevailing NNE trade winds in the region (Fig. 7a) contribute to the resulting plume like shape of the corridor of phosphate industry pollutants (Figs. 8 and 10).

- Tunisia and Eastern Algeria. High concentrations of P are observed in the MCAR plot (Fig. 8c) in the northern part of the border between Algeria and Tunisia, in a corridor that expands from the shore southward to $\sim 32^{\circ} \mathrm{N}$. This region is also significantly affected by emissions of the phosphate mines and P-based fertilizers industry. A number of open mines are distributed in the Tunisian part of the region in Gafsa province (Table 1 and 

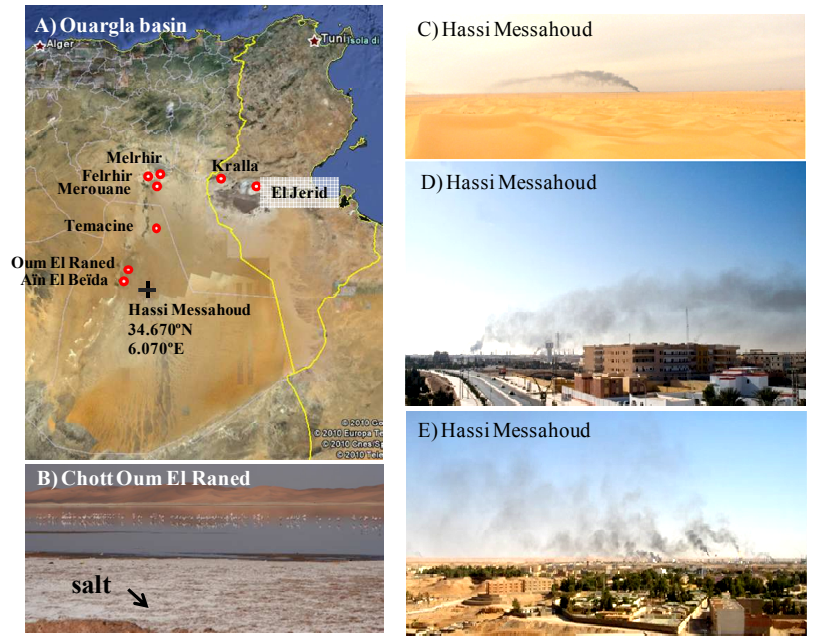

Fig. 12. (A) Ouargla basin, (B) in-situ picture of Chott Oum El Raned, (C-E) in-situ pictures of Hassi Mesahoud.

Fig. 2), with rock processing plants located at: Al Mitlawi $\left(34.340^{\circ} \mathrm{N}, 8.403^{\circ} \mathrm{E}\right), \mathrm{Umm} \mathrm{Al}$ Alaris $\left(34.525^{\circ} \mathrm{N}\right.$, $\left.8.265^{\circ} \mathrm{E}\right)$, Al Rudayyif $\left(34.383^{\circ} \mathrm{N}, 8.145^{\circ} \mathrm{E}\right)$, Gafsa $\left(34.290^{\circ} \mathrm{N}, 8.743^{\circ} \mathrm{E}\right)$, Jallabia, Kef Eddour, Kef Eschfaier and the Mzida. Most of these open mines and processing plants are easily observed from satellite (Fig. 13a), e.g. Gafsa mine $\left(34.290^{\circ} \mathrm{N}, 8.743^{\circ} \mathrm{E}\right)$ and Gafsa processing plant $\left(34.310^{\circ} \mathrm{N}, 8.776^{\circ} \mathrm{E}\right)$. In 2008 , Tunisia produced about $11.6 \mathrm{Mt}$ of raw phosphate rock, of which $879000 \mathrm{t}$ were exported, and the remaining processed in several plants of the country at Gabes (Phosphoric acid, fertilizer and ammonium nitrate production, $\left.33.917^{\circ} \mathrm{N}, 10.093^{\circ} \mathrm{E}\right)$, M'Dhilla (Phosphoric acid and fertilizer production: $34.235^{\circ} \mathrm{N}$, $8.643^{\circ} \mathrm{E}$ ), Sfax (Phosphoric acid and fertilizer production $34.729^{\circ} \mathrm{N}, 10.776^{\circ} \mathrm{E}$ ) and Skhira (Phosphoric acid: $\left.34.346^{\circ} \mathrm{N}, 10.147^{\circ} \mathrm{E}\right)$. The Algerian part of the region is also affected by fertilizer industry emissions. A phosphate mine and rock processing plant is located at Djebe Onk (34.705 $\mathrm{N}, 7.973^{\circ} \mathrm{E}$; Algeria), in Tébessa province. A chemical industrial plant for the production of sulphuric acid $\left(\sim 5 \times 10^{5}\right.$ tons $\left.\mathrm{yr}^{-1}\right)$, phosphoric acid $\left(\sim 1.6 \times 10^{5}\right.$ tons $\left.\mathrm{yr}^{-1}\right)$, diammonium phosphate $\left(\sim 3.3 \times 10^{5}\right.$ tons $\left.\mathrm{yr}^{-1}\right)$ is located at Anabas $\left(36.871^{\circ} \mathrm{N}\right.$, $\left.7.762^{\circ} \mathrm{E}\right)$. These emissions contribute to the high $\mathrm{NO}_{3}^{-}$, $\mathrm{NH}_{4}^{+}$and $\mathrm{SO}_{4}^{=}$concentrations observed (in the MCAR plots) in the region (Fig. 10). The impact of these emissions on the regional air quality was described by AliKhodja et al. (1998) and Azri et al. (2007). In 2008, Algeria produced $1.8 \mathrm{Mt}$ of raw phosphate, a significant fraction being obtained in this area. The fact that soils are rich in phosphate may account for $\mathrm{P}$ emissions from soils in the region simply due to wind blowing. However, the fact that large extensions of soils in the region
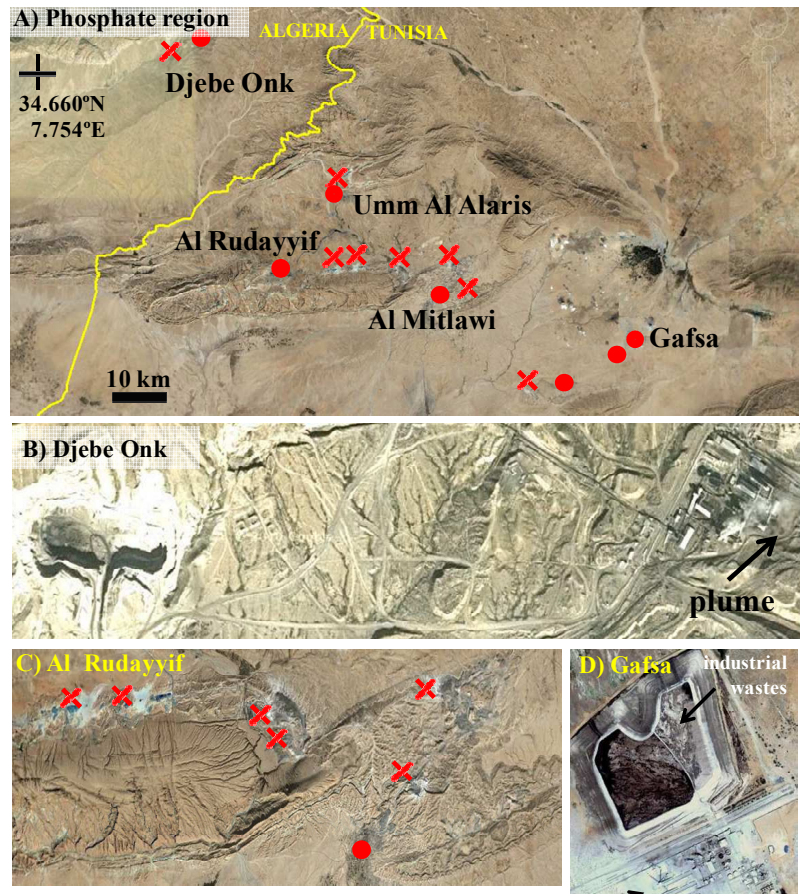

rock management plant $\times$ mines

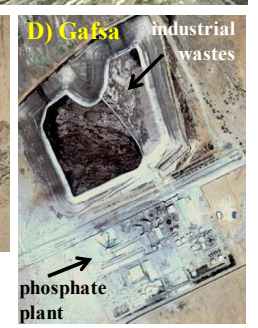

Fig. 13. (A) Satellite view of the phosphate mines region in the border of Algeria (Tébessa province) and Tunisia (Gafsa province). A zoom is shown for Djebe Onk phosphate mines (B), Al Rudayyif (C) and Gafsa (D) mines.

are affected by the open mining activities indicates that part of these regional emissions may be considered as "anthropogenic". The change in the use of soil includes mines, roads, rock management activities and wastes accumulations (Fig. 13b-d). This may account for the high $\mathrm{Al}$ concentrations also observed in this region of the Algeria - Tunisia border (MCAR plots in Fig. 8a).

A region of high $\mathrm{P}$ and $\mathrm{Cl}$ concentrations is observed along a NE to SW corridor over the Ouargla basin (Fig. 8c and e). As far as we know, no industrial and/or mining $\mathrm{P}$ activities occur in this region. Thus, these high $\mathrm{P}$ and $\mathrm{Cl}$ concentrations are attributed to transport from the Tébessa - Gafsa region (mining area) and from the Eastern coast of Tunisia (phosphate based fertilizer industrial area; Fig. 2); i.e. those high $\mathrm{P}$ and $\mathrm{Cl}$ concentrations over Ouargla evidence a transport pathway. This latter process may also contribute to the high $\mathrm{NO}_{3}^{-}, \mathrm{NH}_{4}^{+}, \mathrm{SO}_{4}^{=}$in the region (Fig. 10).

- Central Algeria. A small region of high P concentrations $\left(90-110 \mathrm{ng} \mathrm{m}^{-3}\right.$ ) in the MCAR plot (Fig. 8c) is observed in the central part of the Algerian coast. The region, that expands southward from the shore, is located between Arzew $\left(35.825^{\circ} \mathrm{N} ; 0.293^{\circ} \mathrm{W}\right)$, where a 

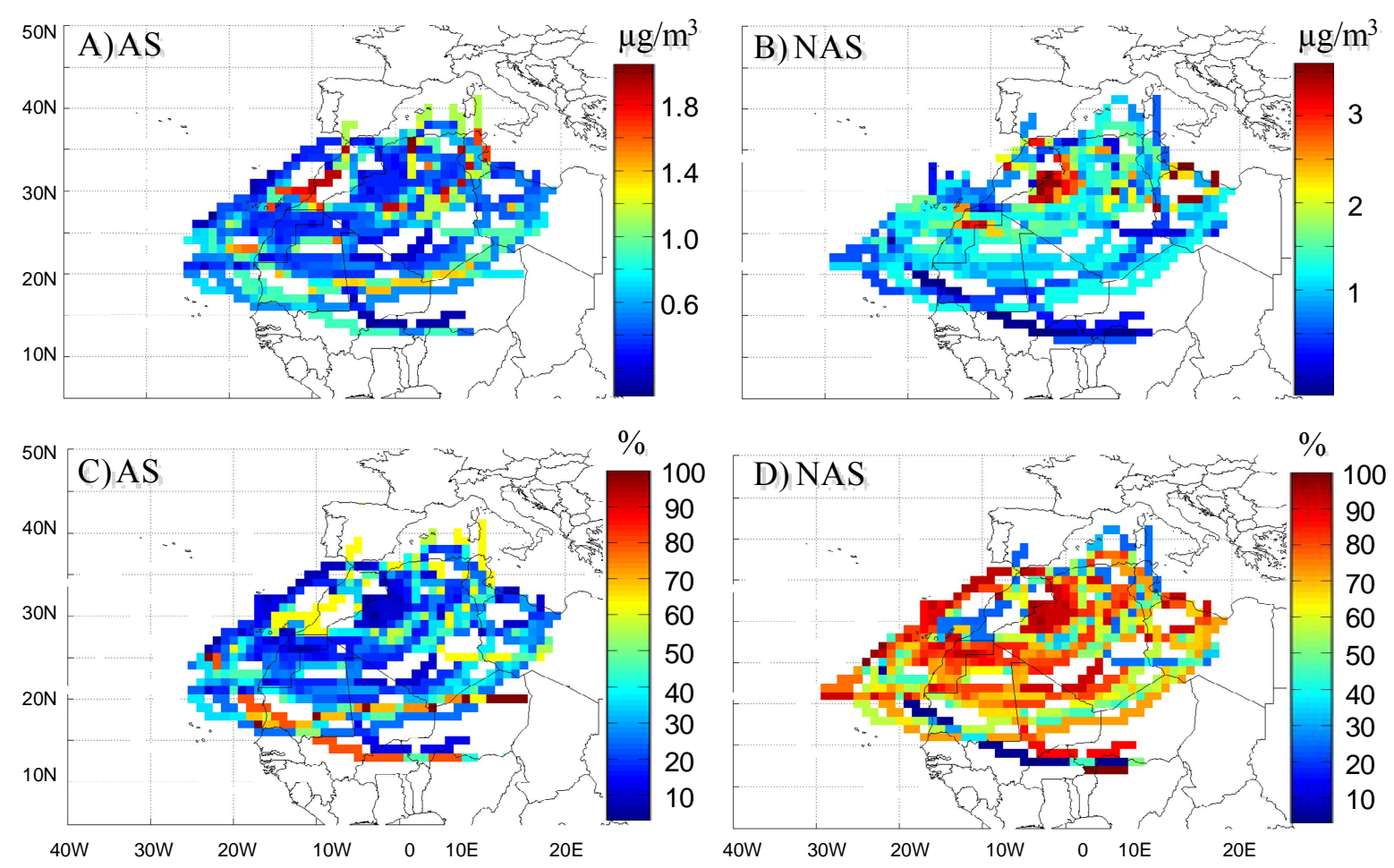

Fig. 14. Median concentrations at receptor (MCAR) plots for ammonium sulphate (AS) and non-ammonium sulphate (NAS), in the PM 10 fraction, in terms of absolute concentration (A-B) and contribution to total sulphate (C-D).

phosphate plant is located, and Beni saf $\left(35.296^{\circ} \mathrm{N}\right.$, $\left.1.338^{\circ} \mathrm{W}\right)$, where phosphate mines are situated.

\subsubsection{Sources of soil sulphate}

Although this study is focused on the contribution of the industrial emissions to the pollutants observed in the SAL, the role of the potential emissions of sulphate from soils (evaporites minerals) will briefly be discussed. Figure 14 shows the MCAR plots for AS and for NAS in terms of concentrations and their contribution to total sulphate. AS concentrations are high over the industrialized regions described above (Morocco, North Algeria, Tunisia and Eastern Algeria), where they account for $60-70 \%$ of the total sulphate (Fig. 14a-c). Concentrations of NAS are high over two well define regions: Bechar (Western Algeria) and Ouargla (Eastern Algeria).

The highest NSA concentrations are recorded in Bechar basin $\left(3-4 \mu \mathrm{g} \mathrm{m}^{-3}\right)$. Because concentrations of ammonium and of nitrate (particulate pollutants) are very low in this region, and because, as far as we know, no industrial activities are present in the region, the high NAS concentrations in Bechar are attributed to emissions of soil sulphate in the region. This interpretation is supported by the analysis of satellite images. As stated above, Bechar region is crossed by a number of dry drainage systems and wadis that converge in topographic lows. A zoom of the satellite images over these topographic lows identifies textures of white crusts combined with fingerprints of water (Fig. 9b and c). This indicates that these areas have been flooded and that salts have been formed by precipitation during the evaporation of water from lakes and lagoons, resulting in the formation of evaporite minerals (e.g. calcium, magnesium and/or sodium sulphate; HamdiAissa et al., 2004). Figure 9b and c show, as an example, two zooms over a topographic low located at the south of the Argelian part of wadi Ouead-Dsoura. The mixing of salts and dust (alluvial deposits) can clearly be observed in the dry lakes. The fact that the MCAR plot for $\mathrm{Ca}$ also shows high concentrations in Bechar province supports the involvement of gypsum and/or anhydrite in the region (Fig. 8b).

Concentrations of NAS are relatively high in Ouargla (Eastern Algeria): $\sim 2 \mu \mathrm{g} \mathrm{m}^{-3}$ in the north and 2.0 $2.5 \mu \mathrm{g} \mathrm{m}^{-3}$ in the south of the basin. Our results suggest that NAS in this region may be affected both by soil and by industrial emissions. A number of saline lakes lie along the axis of this basin, more specifically in the lowest (northern) part of the basin (Fig. 12a): Chott Aïn El Beïda $\left(31.966^{\circ} \mathrm{N}\right.$, $\left.5.372^{\circ} \mathrm{E}\right)$, Chott Oum El Raned $\left(32.040^{\circ} \mathrm{N}, 5.380^{\circ} \mathrm{E}\right)$, Chott Felrhir $\left(34.070^{\circ} \mathrm{N}, 6.050^{\circ} \mathrm{E}\right)$, Chott Merouane $\left(34.136^{\circ} \mathrm{N}\right.$, $\left.5.936^{\circ} \mathrm{E}\right)$ or Chott Melrhir $\left(34.210^{\circ} \mathrm{N}, 6.360^{\circ} \mathrm{E}\right)$. Moreover, dry chotts are also observed in the upper side (southern) of the basin (white spots in Fig. 13a). Studies performed in the region have described how the dust particles of clay-quartzite are accumulated and mixed with the salts around these chotts 
(Rezagi, 1993; Valles et al., 1997; Hamdi-Aissa et al., 2004). Google Earth ${ }^{\mathrm{TM}}$ includes links to a number of in-situ pictures where the crusts of salts are clearly observed (e.g. Fig. 12b). During a SAMUM campaign, Kandler et al. (2009) observed calcium-dominated particles during advections of dust from Chott El Djerid and surroundings (Tunisia - Algeria). Although soils emissions may account for the high sulphate concentrations in Ouargla, the role of the industrial emissions in Hassi Measoud and the transport of pollutants from the North (Northern Algeria - Tunisia) should be also considered. This suggests that a fraction of NAS could be due to coating or interaction of dust particles with anthropogenic sulphate and/or their precursors $\left(\mathrm{SO}_{2} / \mathrm{H}_{2} \mathrm{SO}_{4}\right.$; Alastuey et al., 2005; Desboeufs and Cautenet, 2005; Dall'Osto et al., 2010). In fact, the highest NAS concentrations in Ouargla basin are observed over and downwind of Hassi Messahoud. The high $\mathrm{Ca}$ concentrations observed in the MCAR plot in this region point to the presence of Ca-sulphate (Fig. 8b).

\subsection{Positive Matrix Factorization modelling}

The PMF2 model was used to identify the chemical profile of the sources that contribute to $\mathrm{PM}_{10}$ in the summer subtropical SAL. This was done for assessing the consistency of the above performed interpretations on the origin of the pollutants mixed with dust. Three potential sources affecting the levels and chemical composition of $\mathrm{PM}_{10}$ were identified (Fig. 15):

1. Source 1 is traced by typical soil dust elements: $\mathrm{Al}$, $\mathrm{Ca}, \mathrm{Fe}, \mathrm{Mg}, \mathrm{Mn}, \mathrm{Ti}, \mathrm{Rb}, \mathrm{Sr}, \mathrm{La}$ and $\mathrm{K}$. According to the model, this source accounts for $22.0 \mu \mathrm{g} \mathrm{m}^{-3}$ as averaged, i.e. $75 \%$ of bulk $\mathrm{PM}_{10}$. Moreover, it accounted for $22 \%, 16 \%$ and $96 \%$ of the measured concentrations of $\mathrm{SO}_{4}^{=}, \mathrm{NO}_{3}^{-}$and Ca respectively as average during the whole study period. This source was also enriched in $\mathrm{P}$ and accounted for $\sim 60 \%$ of the mean concentration of this element. The $\mathrm{Fe} / \mathrm{Al}, \mathrm{K} / \mathrm{Al}, \mathrm{Mg} / \mathrm{Al}, \mathrm{Ca} / \mathrm{Al}$ ratios in the chemical profile of this source were 0.53, 0.20, $0.16,0.34$, respectively in good agreement with the previously reported ratios calculated from the measured ambient concentrations of these elements (Table 3).

2. Source 2 shows a profile traced by $\mathrm{SO}_{4}^{=}, \mathrm{Ca}, \mathrm{Na}, \mathrm{Mg}$, $\mathrm{V}, \mathrm{Ni}, \mathrm{As}, \mathrm{Pb}, \mathrm{P}$ and $\mathrm{NO}_{3}^{-}$. The concentration of $\mathrm{NH}_{4}^{+}$ in the chemical profile of this source is almost negligible. The profile of the source includes $\mathrm{SO}_{4}^{=}$and $\mathrm{NO}_{3}^{-}$, present as $\mathrm{Ca}, \mathrm{Na}$ and/or $\mathrm{Mg}$ (only for sulphate) salts, and potential industrial tracers, such as $\mathrm{V}, \mathrm{Ni}, \mathrm{As}$, and $\mathrm{Pb}$. The presence of species potentially affected by anthropogenic emissions (e.g. $\mathrm{SO}_{4}^{=}, \mathrm{Ni}, \mathrm{As}, \mathrm{Pb}$ ) with soil dust elements (e.g. $\mathrm{Ca}$, Na) suggest that this source is related with interaction between pollutants and dust. As average during the whole study period, this source accounted for $4.4 \mu \mathrm{g} \mathrm{m}^{-3}$ of $\mathrm{PM}_{10}$ (15\% of bulk mass) and for $52 \%, 28 \%, 2 \%$ and $20 \%$ of $\mathrm{SO}_{4}^{=}, \mathrm{NO}_{3}^{-}, \mathrm{Ca}$ and $\mathrm{P}$ respectively.

3. Source 3 exhibits a chemical profile characterised by $\mathrm{SO}_{4}^{=}, \mathrm{NO}_{3}^{-}, \mathrm{NH}_{4}^{+}, \mathrm{Cl}$ and $\mathrm{P}$. This profile fits with that observed in the regions where emissions from the phosphate based fertilizer industry is present: Morocco, Eastern Algeria and Tunisia (Figs. 8e, f and 10). This source accounts for the presence of ammonium-sulphate $\left[\left(\mathrm{NH}_{4}\right)_{2} \mathrm{SO}_{4}\right]$ and ammoniumnitrate $\left[\mathrm{NH}_{4} \mathrm{NO}_{3}\right]$, even if the latter is expected to be present in very low concentrations. The ratios of these compounds in the chemical profile were 0.37 and 0.35 respectively, very close to the stoichiometric ratios for ammonium sulphate and nitrate (Chow et al., 1992). This source accounted for $2.3 \mu \mathrm{g} \mathrm{m}^{-3}$ of $\mathrm{PM}_{10}$ (8\% of bulk mass) and $22 \%, 53 \%, 0 \%$ and $20 \%$ of sulphate, nitrate, $\mathrm{Ca}$ and $\mathrm{P}$, respectively.

In general, the contributions of the various sources obtained with PMF should be independent of one other if unrealistic rotations are not present in the solution. However, a certain degree of correlation between specific source pairs can be observed if physical and/or chemical atmospheric processes constrain such sources to be correlated (Kim and Hopke, 2008; Pandolfi et al., 2011). In our case the moderate to high correlation observed between the three profiles of sources, illustrated in Fig. 15b-d, evidence that the pollutants are very well mixed with dust. At remote sites such as Izaña, aerosols are aged and very well mixed, resulting in a relatively homogenous aerosol. This decreases the number of sources that may be properly identified by receptor modelling.

\section{Summary, discussion and conclusions}

Particulate matter samples (TSP, $\mathrm{PM}_{10}$ and $\mathrm{PM}_{2.5} ; \mathrm{PM}_{\mathrm{x}}$ ) representative of the northern side of the summer Saharan Air Layer (SAL) were collected in the North Atlantic free troposphere at Izaña Global Atmospheric Watch observatory (Tenerife, Canary Islands). An analysis of the chemical composition of these $\mathrm{PM}_{\mathrm{x}}$ samples shows that soil desert dust is very frequently mixed with particulate pollutants. The results of this study evidence that:

- The areas located at the south of the southern slope of the Atlas mountains are a significant source of soil dust advected toward the Atlantic in summer in the northern edge of the Saharan Air Layer.

- Emissions from the crude oil refineries, "phosphate based fertilizer industry" and power plants, located in the Atlantic coast of Morocco, Northern Algeria, Easter Algeria and Tunisia, significantly contribute to mix desert dust with particulate pollutants such as nitrate, sulphate and ammonium. The chemical composition of 

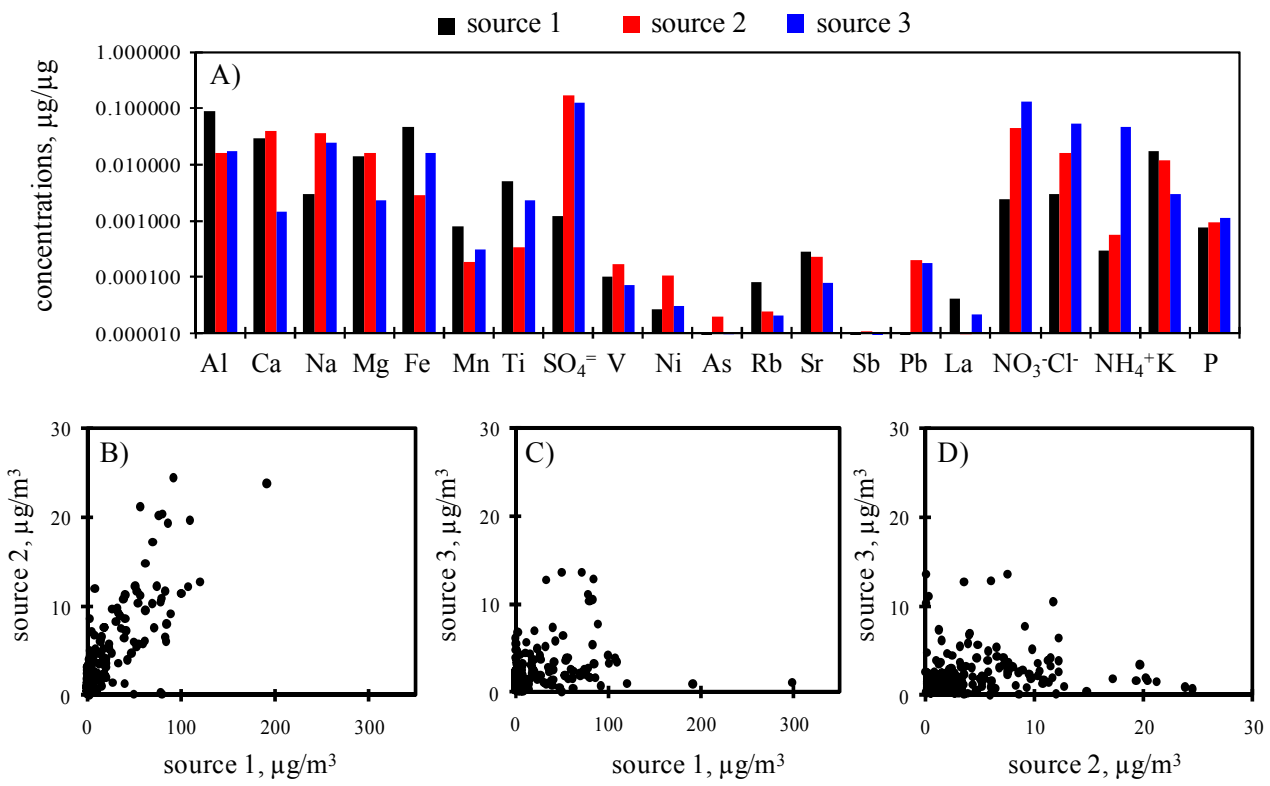

Fig. 15. Chemical profile (A) and contributions (B-D) obtained by applying the PMF2 model to the $\mathrm{PM}_{10}$ composition at Izaña.

$\mathrm{PM}_{\mathrm{x}}$ and the size distribution data suggest that both internal and external mixing may occur in the aerosol population present in the SAL.

- The land use change and the industrial activities in some parts of North Africa may be influencing the regional dust emissions rates. This may be especially important for some compounds. A clear example is the case of phosphate. The results of this study show that, although desert dust emissions are the most important North African source of phosphorous, high P concentrations and high $\mathrm{P} / \mathrm{Al}$ ratios are recorded in the SAL due to emissions in the Atlantic coast of Morocco, Tunisia and Algeria linked to phosphate mines and P-based fertilizer industry. These high emissions rates of $\mathrm{P}$ we have observed over these regions are in agreement with experimental observations performed by Guieu et al. (2010), who observed the highest deposition rates of $\mathrm{P}$ in the Mediterranean sea in the coast of Tunisia.

- Emissions of soil evaporite minerals (e.g. $\mathrm{Ca}, \mathrm{Mg}$ or $\mathrm{Na}$ sulphate) and industrial $\mathrm{SO}_{2} / \mathrm{SO}_{\mathrm{x}}$ contribute to the sulphate concentrations typically observed in the SAL. In an attempt to quantify the contribution of North African anthropogenic activities, sulphate was segregated in two components, sulphate present as ammonium-sulphate (considered anthropogenic) and sulphate present as non-ammonium-sulphate. This later form of sulphate is affected by both soil emissions of evaporite minerals and by coating and interaction of dust particles with sulphate and/or their precursors $\left(\mathrm{SO}_{2} / \mathrm{H}_{2} \mathrm{SO}_{4}\right)$ due to anthropogenic emissions. The highest ammonium- sulphate concentrations are observed when the SAL is mixed with pollutants emitted in industrial regions of Morocco, Eastern Algeria, Northern Algeria and Tunisia, when it accounts for $60-70 \%$ of the sulphate present in the SAL. The highest non-ammoniumsulphate concentrations are observed in regions where satellite images show an abundance of crust of salts on topographic lows, and where salt dry lakes (chotts) are clearly observed (Bechar and Ouargla regions). In these cases, non-ammonium-sulphate accounts for 80 $90 \%$ of the sulphate observed in the SAL. High nonammonium-sulphate concentrations are also observed in regions where anthropogenic $\mathrm{SO}_{2} / \mathrm{SO}_{\mathrm{x}}$ emissions occur; there coating of dust particles by anthropogenic sulphate is expected to occur (e.g. Ouargla). Further developments are necessary for segregating the soil evaporites and the dust coating related sulphate from the nonammonium-sulphate fraction.

The results of this and of previous studies evidence that more investigations are needed to enable a comprehensive view of the processes involved in the desert dust and pollutants mixings, and their implications on the physicochemical properties of the SAL. Studies performed by Millán et al. (1997) and Gangoiti et al. (2006) have shown that aged pollutants emitted in Eastern Spain and re-circulated in the Western Mediterranean basin may also be mixed with North African desert dust, and then be exported to the North Atlantic in the SAL. These coastal and mountain breezes involved in the regional transport and aging of pollutants have also been described for the North African side of the Western Mediterranean (Algeria - Tunisia; Bouchlaghem et al., 
2007). Southward transport of particulate pollutants from urban coastal areas of Algeria to Saharan inner sites (across Atlas) was also described by Yassaa et al. (2001c). In addition to recirculation processes linked to the topographic setting in the Western Mediterranean, north-to-south corridors in the "Central Mediterranean" and in the "strait of Gibraltar - Morocco" may favour the "quick transport" pathways from Europe to North Africa (Kallos et al., 1998; Astitha et al., 2010). Similarly, long range transport of dust plus pollutants mixings has been documented in the Eastern Mediterranean (Erel et al., 2006; Kalderon-Asael et al., 2009).

Acknowledgements. This study has been carried out within the Global Atmospheric Watch Program (financed by AEMET), and in the framework of the research projects GRACCIE (CSD200700067; Ministry of Science and Innovation of Spain), CARIATI (CGL2008-06294/CLI; Ministry of Science and Innovation of Spain), AER-REG (P07-RNM-03125; Department of Innovation, Science and Enterprise of the Government of Andalusia) and REDMAAS (CGL2010-11095-E; Ministry of Science and Innovation of Spain). We thank NOAA Air Resources Laboratory for the facilities (software and data) for determining back-trajectories, NOAA Earth System Research Laboratory for providing meteorological tools, NASA Goddard Earth Sciences Data and Information Service Centre (Giovanni service) for providing Aerosol Index data and Google Earth ${ }^{\mathrm{TM}}$, Google map ${ }^{\mathrm{TM}}$ and Panoramio ${ }^{\mathrm{TM}}$. We distinguish the excellent work performed by the staff in charge of the aerosol sampling: Fernando de Ory, Carlos Torres, Virgilio Varreño, Cándida Hernández, Julián Pérez, Daniel Martín, Rubén Del Campo, Cesar López, Marco Hernández, Damián Expósito, Antonio Hernández and Jose Hernández.

Edited by: N. Mihalopoulos

\section{References}

Alastuey, A., Querol, X., Castillo, S., Escudero, M., Avila, A., Cuevas, E., Torres, C., Romero, P.M., Exposito, F., Garcia, O., Diaz, J. P., Dingenen, R. V., and Putaud, J. P.: Characterisation of TSP and PM2.5 at Izaña and Sta. Cruz de Tenerife (Canary Islands, Spain) during a Saharan dust episode (July 2002), Atmos. Environ., 39(26), 4715-4728, 2005.

Amato, F., Pandolfi, M., Escrig, A., Querol, X., Alastuey, A., Pey, J., Perez, N., and Hopke, P. K.:Quantifying road dust resuspension in urban environment by multilinear engine: a comparison with PMF2, Atmos Environ., 43, 2770-2780, 2009.

Ali-Khodja, H. and Kebabi, B.: Assessment of wet and dry deposition of $\mathrm{SO}_{2}$ attribuible to a sulphuric acid plant at Annaba, Algeria, Environ. Int., 24(7), 799-807, 1998.

Ali-Khodja, H., Belaala, A., Demmane-Debbih, W., Habbas, B., and Boumagoura, N.: Air quality and deposition of trace elements in Didouche Mourad, Algeria, Environ. Monit. Assess., 138, 219-231, 2008.

Astitha, M., Kallos, G., Spyrou, C., O'Hirok, W., Lelieveld, J., and Denier van der Gon, H. A. C.: Modelling the chemically aged and mixed aerosols over the eastern central Atlantic Ocean potential impacts, Atmos. Chem. Phys., 10, 5797-5822, doi:10.5194/acp-10-5797-2010, 2010.
Azri, C., Medhioub, K.,, and Rosset, R.: Evolution of atmospheric pollutants in the city of Sfax (Tunisia) October 1996-June 1997, Atmósfera, 20(3), 223-246, 2007.

Birch, M. and Cary, R.: Elemental carbon-based method for monitoring occupational exposures to diesel particulate diesel exhaust, Aerosol Sci. Technol., 25, 221-241, 1996.

Bouchlaghem, K., Ben Mansour, F., and Elouragin, S.: Impact of a sea breeze event on air pollution at the Eastern Tunisian Coast, Atmos. Res., 86, 162-172, 2007.

Brooks, N.: Dust-climate interactions in the Sahel-Sahara zone of northern Africa, with particular reference to late twentieth century Sahelian drought. PhD thesis, Norwich Climatic Research Unit, University of East Anglia, United Kingdom, 2000.

Brooks, N. and Legrand, M.: Dust variability over northern Africa and rainfall in the Sahel, Linking Climate Change to Land Surface Change, edited by: McLaren, S. J. and Kniveton, D., 1-25, Kluwer Academic Publishers, 2000.

Capes, G., Johnson, B., McFiggans, G., Williams, P. I., Haywood, J., and Coe, H.: Aging of biomass burning aerosols over West Africa: Aircraft measurements of chemical composition, microphysical properties, and emission ratios, J. Geophys. Res., 113, D00C15, doi:10.1029/2008JD009845, 2008.

Chorowicz, J. and Fabre, J.: Organization of drainage networks from space imagery in the Tanezrouft (Western Sahara): implications of recent intracratonic deformations, Geomorphology, 21, 139-151, 1997.

Chow, J. C., Watson, J. G.,. Lowenthal, D. H., Solomon, P. A., Magliano, K. M., Ziman, S. D., and Richards, L. W.: PM $_{10}$ Source Apportionment in California's San Joaquin Valley, Atmos. Environ., 26A(18), 3335-3354, 1992.

Claquin, T., Schulz, M., and Balkanski, Y.J.: Modeling the mineralogy of atmospheric dust sources, J. Geophys. Res., 104(D18), 22243-22256, 1999.

CNEDD Report: Charte Nationale de l'Environnement et du Développement Durable (CNEDD), Rapport Sur La Pollution de Air, 2007.

Dall'Osto, M., Harrison, R. M., Highwood, E. J., O'Dowd, C., Ceburnis, D., Querol, X., and Achterberg, E. P.: Variation of the mixing state of Saharan dust particles with atmospheric transport, Atmos. Environ., 44, 3135-3146, 2010.

Desboeufs, K. V. and Cautenet, G.: Transport and mixing zone of desert dust and sulphate over Tropical Africa and the Atlantic Ocean region, Atmos. Chem. Phys. Discuss., 5, 56155644, doi:10.5194/acpd-5-5615-2005, 2005.

Draxler, R. R. and Rolph, G. D.: HYSPLIT (HYbrid Single-Particle Lagrangian Integrated Trajectory) Model access via NOAA ARL READY Website (http://ready.arl.noaa.gov/HYSPLIT. php), NOAA Air Resources Laboratory, Silver Spring, MD, 2010.

Engelstaedter, S., Tegen, I., and Washington, R.: North African dust emissions and transport, Earth Sci. Rev., 79, 73-100, 2006.

Erel, Y., Dayan U., Rabi, R., Rudich, Y., and Stein, M.: Trans Boundary Transport of Pollutants by Atmospheric Mineral Dust, Environ. Sci. Technol., 40, 2996-3005, 2006.

Erramli, H., Gogon, H. D., Misdaq, M. A., Sauvage, T., and Ramboz, C.: Study of pollution in the El Jadida-Safi Atlantic coastal zone (Morocco) by using PIXE and SSNTD methods, Journal of Environmental Radioactivity, 99, 1216-1223, 2008.

Escrig, A., Monfort, E., Celades, I., Querol, X., Amato, F., Min- 
guillón, M. C., and Hopke, P. H.: Application of Optimally Scaled Target Factor Analysis for Assessing Source Contribution of Ambient $\mathrm{PM}_{10}$, J. Air Waste Manage. Assoc., 59, 1296-1307, 2009.

Falkowski, P. G., Barber, R. T., and Smetacek, V.: Biogeochemical controls and feedbacks on ocean primary production, Science, 281, 200-206, 1998.

Formenti, P., Elbert, W., Maenhaut, W., Haywood, J., and Andreae, M. O.: Chemical composition of mineral dust aerosol during the Saharan Dust Experiment (SHADE) airborne campaign in the Cape Verde region, September 2000, J. Geophys. Res., 108(D18), 8576, doi:10.1029/2002JD002648, 2003.

Formenti, P., Rajot, J. L., Desboeufs, K., Caquineau, S., Chevaillier, S., Nava, S., Gaudichet, A., Journet, E., Triquet, S., Alfaro, S., Chiari, M., Haywood, J., Coe, H., and Highwood, E.: Regional variability of the composition of mineral dust from western Africa: Results from the AMMA SOP0/DABEX and DODO field campaigns, J. Geophys. Res., 113, D00C13, doi:10.1029/2008JD009903, 2008.

Gangoiti, G., Alonso, L., Navazo, M., García, J. A., and Millán, M. M.: North African soil dust and European pollution transport to America during the warm season: Hidden links shown by a passive tracer simulation, J. Geophys. Res., 111, D10109, doi:10.1029/2005JD005941, 2006.

Gaudry, A., Zeroual, S., Gaie-Levrel, F., Moskura, M., Boujrhal, F. Z., Cherkaoui El Moursli, R., Guessous, A., Mouradi, A., Givernaud, T., and Delmas, R.: Heavy metals pollution of the Atlantic Marine Environment by the Moroccan Phosphate Industry, as Observed through their bioaccumulation in Ulva Lactuca, Water Air Soil Pollut., 178, 267-285, 2007.

Ginoux, P., Prospero, J. M., Torres, O., and Chin, M.: Long-term simulation of global dust distribution with the GOCART model: correlation with North Atlantic Oscillation, Environ. Modell. Softw., 19, 113-128, 2004.

Guieu, C., Loÿe-Pilot, M. D., Benyahya, L., and Dufour, A.: Spatial variability of atmospheric fluxes of metals (Al, Fe, Cd, $\mathrm{Zn}$ and $\mathrm{Pb}$ ) and phosphorus over the whole Mediterranean from a oneyear monitoring experiment: Biogeochemical implications, Mar. Chem., 120, 164-178, 2010.

Hamdi-Aissa, B., Valles, V., Aventurier, A., and Ribolzi, O.: Soils and brine geochemistry and mineralogy of hyperarid desert playa, Ouargla basin, Algerian Sahara. Arid Land, Research and Management, 18, 103-126, 2004.

Haywood, J., Francis, P., Osborne, S., Glew, M., Loeb, N., Highwood, E., Tanre, D., Myhre, G., Formenti, P., and Hirst, E.: Radiative properties and direct radiative effect of Saharan dust measured by the C-130 aircraft during SHADE: 1 . Solar spectrum, J. Geophys. Res., 108(D18), 8577, doi:10.1029/2002JD002687, 2003.

Jiménez, E., Linares, C., Martínez, D., and Díaz, J.: Role of Saharan dust in the relationship between particulate matter and short-term daily mortality among the elderly in Madrid (Spain), Sci. Total Environ., 408(23), 5729-5736, 2010.

Juntto, S. and Paatero, P.: Analysis of daily precipitation data by positive matrix factorization, Environmetrics, 5, 127-144, 1994.

Kallos, G., Kotroni, V., Lagouvardos, K., and Papadopoulos, A.: On the long range transport of air pollutants from Europe to Africa, Geophys. Res. Lett., 25, 619-622, 1998.

Kalderon-Asael, B., Erel, Y., Sandler, A., and Dayan, U.: Miner- alogical and chemical characterization of suspended atmospheric particles over the east Mediterranean based on synoptic-scale circulation patterns, Atmos. Environ., 43, 3963-3970, 2009.

Kandler, K., Benker, N., Bundke, U., Cuevas, E., Eberta, M., Knippertz, P., Rodríguez, S., Schütz, L., and Weinbruch, S.: Chemical composition and complex refractive index of Saharan Mineral Dust at Izaña, Tenerife (Spain) derived by electron microscopy, Atmos. Environ., 41, 8058-8074, 2007.

Kandler, K., Schültz, L., Deutscher, C., Ebert, M., Hofmann, H., Jäckel, S., Jaenicke, R., Knippertz, P., Lieke, K., Massling, A., Petzol, A., Schladitz, A., Weinzierl., B., Wiedensohler, A., Zorn, S., and Weinbruch, S.: Size distribution, mass concentration, chemical and mineralogical composition and derived optical parameters of the boundary layer aerosol at Tinfou, Morocco, during SAMUM 2006, Tellus, 61B, 32-50, 2009.

Khatami, A., Ponche, J. L., Jabry, E., and Mirabel, Ph.: The air quality management of the region of Great Casablanca (Morocco). Part 1: atmospheric emissions inventory for the year 1992, Sci. Total. Environ., 209, 201-216, 1998.

Kim, E. and Hopke, P. K.: Source characterization of ambient fine particles at multiple sites in the Seattle area, Atmos. Environ., 42, 6047-6056, 2008.

Knippertz, P., Deutscher, C., Kandler, K., Müller, T., Schulz, O., and Schütz, L.: Dust mobilization due to density currents in the Atlas region: Observations from the Saharan Mineral Dust Experiment 2006 field campaign, J. Geophys. Res., 112, D21109, doi:10.1029/2007JD008774, 2007.

Knippertz, P., Ansmann, A., Althausen, D., Müller, D., Tesche, M., Bierwirth, E., Dinter, T., Müller, T., Von Hoyningen-Huene, W., Schepanski, K., Wendisch, M., Heinold, B., Kandler, K., Petzold, A., Schütz, L., and Tegen, I.: Dust mobilization and transport in the northern Sahara during SAMUM 2006 - a meteorological overview, Tellus, 61B, 12-31, 2009.

Levin, Z., Ganor, E., and Gladstein, V.: The effects of desert particles coated with sulfate on rain formation in the eastern Mediterranean, J. Appl. Meteorol., 35, 1511-1523, 1996.

Li, W. J. and Shao, L. Y.: Observation of nitrate coatings on atmospheric mineral dust particles, Atmos. Chem. Phys., 9, 18631871, doi:10.5194/acp-9-1863-2009, 2009.

Li-Jones, X. and Propero, J. M.: Variations in the size distribution of non-sea salt sulfate aerosol in the marine boundary layer at Barbados: Impact of African dust, J. Geophys. Res., 103, 1607316084, 1998.

Li-Jones, X., Maring, H. B., and Propero, J. M.: Effect of relative humidity on light scattering by mineral dust aerosol as measured in the marine boundary layer over the tropical Atlantic Ocean, J. Geophys. Res., 113, 31113-31121, 1998.

Maring, H., Savoie, D. L., Izaguirre, M. A., Custals, L., and Reid, J. S.: Mineral dust aerosol size distribution change during atmospheric transport, J. Geophys. Res., 108(D19), 8592, doi:10.1029/2002JD002536, 2003.

Michaels, A. F., Olson, D., Sarmineto, J. L., Ammerman, J. W., Fanning, K., Jahnke, R., Knap, A. H., Lipschultz, F., and Prospero, J. M.: Inputs, losses and transformations of nitrogen and phosphorus in the pelagic North Atlantic Ocean, Biogeochemistry, 35, 181-226, 1996.

Middleton, N., Yiallouros, P., Kleanthous, S., Kolokotroni, O., Schwartz, J., Dockery, D. W., Demokritou, P., and Koutrakis, P.: A 10-year time-series analysis of respiratory and cardiovas- 
cular morbidity in Nicosia, Cyprus: the effect of short- term changes in air pollution and dust storms, Environ. Health, 7(39), doi:10.1186/1476-069X-7-39, 2008.

Millán, M. M., Salvador, R., Mantilla, E., and Kallos, G.: Photooxidant dynamics in the western Mediterranean in summer: Results from European research projects, J. Geophys. Res., 102(D7), 8811-8823, 1997.

Mills, M.M., Ridame, C., Davey, M., La Roche, J., and Geider, R. J.: Iron and phosphorus co- limit nitrogen fixation in the eastern tropical North Atlantic, Nature 429, 292-294, 2004.

Newman, H. R.: The mineral industries of Morocco and Western Sahara, 2008 Mineral Yearbook, USGS publications, available at: http://minerals.usgs.gov/minerals/pubs/country/africa.html\# ag, 2008.

Paatero, P.: Least square formulation of robuste non-negative factor analysis, Chemometr. Intell. Lab. Syst., 3, 23-35, 1997.

Paatero, P. and Hopke, P. K.: Discarding or downweighting highnoise variables in factor analytic models, Anal Chim Acta, 490, 277-289, 2003.

Paatero, P. and Tapper, U.: Positive matrix factorization: a nonnegative factor model with optimal utilization of error estimates of data values, Environmetrics, 5, 111-126, 1994.

Paatero, P., Hopke, P. K., Song, X., and Ramadan, Z.: Understanding and controlling rotations in factor analytic models, Chemometrics and Intelligent Laboratory Systems, 60(1-2), 253-264, 2002.

Paatero, P., Hopke, P. K., Begum, B. A., and Biswas, S. K.: A graphical diagnostic method for assessing the rotation in factor analytical models of atmospheric pollution, Atmos. Environ., 39, 193-201, 2005.

Pandolfi, M., Gonzalez-Castanedo, Y., Alastuey, A., de la Rosa, J. D., Mantilla, E., Sanchez de la Campa, A., Querol, X., Pey, J., Amato, F., and Moreno, T.: Source apportionment of $\mathrm{PM}_{10}$ and $\mathrm{PM}_{2.5}$ at multiple sites in the strait of Gibraltar by PMF: impact of shipping emissions, Environ. Sci. Pollut. Res., 18, 260-269, 2011.

Pérez, L., Tobias, A., Querol, X., Künzli, N., Pey, J., Alastuey, A., Viana, M., Valero, N., González-Cabré, M., and Sunyer, J.: Coarse Particles From Saharan Dust and Daily Mortality, Epidemiology, 19(6), 800-807, 2008.

Prospero, J. M.: Long-term measurements of transport of African mineral dust to the southeast United States: Implications for the regional air quality, J. Geophys. Res., 104, 15917-15927, 1999.

Prospero, J. M., Schmitt, R., Cuevas, E., Savoie, D. L., Graustein, W. C., Turekian, K. K., Volz-Thomas, A., DmHaz, A., Oltmans, S.J., and Levy II, H.: Temporal variability of summer-time ozone and aerosols in the free troposphere over the eastern North Atlantic, Geophys. Res. Lett., 22, 2925-2928, 1995.

Prospero, J. M., Olmez, I., and Ames, M.: $\mathrm{Al}$ and Fe in $\mathrm{PM}_{2.5}$ and $\mathrm{PM}_{10}$ suspended particles in South-Central Florida: the impact of the long range transport of African mineral dust, Water Air Soil Pollut., 125, 291-317, 2001.

Prospero, J. M., Ginoux, P., Torres, O., Nicholson, S. E., and Gill, T. E.: Environmental characterizacion of global sources of dust with the Nimbus 7 total ozone mapping spectrometer (TOMS) absorbing aerosol product, Rev. Geophys., 40(1), 1002, doi:10.1029/2000RG000095, 2002.

Putaud, J. P., Van Dingenen, R., Mangoni, M., Virkkula, A., Raes, F., Maring, H., Prospero, J. M., Swietlicki, E., Berg, O. H.,
Hillamo, R., and Mäkela, T.: Chemical mass closure and assessment of the origin of the submicron aerosol in the marine boundary layer and the free troposphere at Tenerife during ACE2, Tellus, 52B, 141-168, 2000.

Querol, X., Alastuey, A., Rodríguez, S., Plana, F., Mantilla, E., and Ruiz, C. R.: Monitoring of $\mathrm{PM}_{10}$ and $\mathrm{PM}_{2.5}$ around primary particulate anthropogenic emission sources, Atmos. Environ., 35, 845-858, 2001.

Querol, X., Pey, J., Minguillón, M. C., P'erez, N., Alastuey, A., Viana, M., Moreno, T., Bernabé, R. M., Blanco, S., Cárdenas, B., Vega, E., Sosa, G., Escalona, S., Ruiz, H., and Artíñano, B.: PM speciation and sources in Mexico during the MILAGRO-2006 Campaign, Atmos. Chem. Phys., 8, 111-128, doi:10.5194/acp8-111-2008, 2008.

Reid, E. A., Reid, J. S., Meier, M. M., Dunlap, M. R., Cliff, S. S., Broumas, A., Perry, K., and Maring, H.: Characterization of African dust transported to Puerto Rico by individual particle and size segregated bulk analysis, J. Geophys. Res., 108(D19), 8591, doi:10.1029/2002JD002935, 2003.

Rezagi, M.: Dynamique des sels dans les eaux et les plantes halophytes (Salicornia L.) dans deux régions arides (Algérie et Espagne), Ph.D. thesis, Université d'Annaba, Algeria, 1993.

Rodríguez, S., Van Dingenen, R., Putaud, J.-P., Dell'Acqua, A., Pey, J., Querol, X., Alastuey, A., Chenery, S., Ho, K.-F., Harrison, R., Tardivo, R., Scarnato, B., and Gemelli, V.: A study on the relationship between mass concentrations, chemistry and number size distribution of urban fine aerosols in Milan, Barcelona and London, Atmos. Chem. Phys., 7, 2217-2232, doi:10.5194/acp-7-2217-2007, 2007.

Rodríguez, S., González, Y., Cuevas, E., Ramos, R., Romero, P. M., Abreu-Afonso, J., and Redondas, A.: Atmospheric nanoparticle observations in the low free troposphere during upward orographic flows at Izaña Mountain Observatory, Atmos. Chem. Phys., 9, 6319-6335, doi:10.5194/acp-9-6319-2009, 2009.

Savoie, D. L., Prospero, J. M., Oltmans, S. J., Graustein, W. C., Turekian, K. K., Merril, J. T., and Levy II, H.: Sources of nitrate and ozone in the marine boundary layer of the Tropical North Atlantic, J. Geophys. Res., 97(11), 575-589, 1992.

Schaap, M., Müller, K., and ten Brink, H. M.: Constructing the European aerosol nitrate concentration field from air quality analysed data, Atmos. Environ., 36, 1323-1335, 2002.

Schütz, L. and Sebert, M.: Mineral aerosols and source Identification, J. Aerosol Sci., 18, 1-10, 1987.

Sunnu, A., Afeti, G., and Resch, F.: A long-term experimental study of the Saharan dust presence in West Africa, Atmos. Res., 87, 13-26, 2008.

Taib, M.: The mineral industries of Algeria, 2008 Mineral Yearbook. USGS publications, available at: http://minerals.usgs.gov/ minerals/pubs/country/africa.html\#ag, 2008a.

Taib, M.: The mineral industries of Tunisia. 2008 Mineral Yearbook, USGS publications, available at: http://minerals.usgs.gov/ minerals/pubs/country/africa.html\#ag, 2008b.

Tlili, N., Zarrouk, S., Boughediri, L., and Chaoui, F.: Bio-indication of air quality in the Annaba city (East of Algeria), Research Journal of Biological Sciences, 2(6), 617-619, 2007.

Torres, O., Bhartia, P. K., Herman, J. R., Ahmad, Z., and Gleason, J.: Derivation of aerosol properties from a satellite measurements of backscattered ultraviolet radiation: Theoretical basis, J. Geophys. Res., 103, 17099-17110, 1998. 
Yassaa, N. and Cecinato, A.: Composition of torched crude oil organic particulate emitted by refinery and its similarity to atmospheric aerosol in the surrounding area, Chemosphere, 60, 6601666, 2005.

Yassaa, N., Meklati, B. Y., Cecinato, A., Marino, F., and Balducci, C.: Organic content of particulate matter in the atmosphere of Ouargla city, Algeria, Ann. Chim- Rome, 91, 577-585, 2001a.

Yassaa, N., Meklati, B. Y., and Cecinato, A.: Chemical characteristics of organic aerosols in Algiers city area: influence of a fat manufacture plant, Atmos. Environ., 35, 6003-6013, 2001b.

Yassaa, N., Meklati, Y., Brancaleoni, E., Frattoni, M., and Ciccioli, P.: Polar and non- polar volatile organic compounds (VOCs) in urban Algier and Saharan sites of Algeria, Atmos. Environ., 35, 787-801, 2001c.
Valles, V., Rezagui, M., Auque, L., Semadi, A., Roger, L., and Zouggari, H.: Geochemistry of saline soils in two arid zones of the Mediterranean basin. I. Geochemistry of the Chott Melghir - Mehrouane watershed in Algeria, Arid Soil Res. Rehab., 11, 71-84, 1997.

Weinzierl, B., Petzol, A., Esselborn, M., Wirth, M., Raps, Kandler, K., Schütz, L., Koepke, P., and Fiebig, M.: Airborne measurements of dust layer properties, particle size distribution and mixing state of Saharan dust during SAMUM 2006, Tellus, 61B, 96-117, 2009.

Zender, C. S., Miller, R. L., and Tegen, I.: Quantifying mineral dust mass budgets: terminology, constraints, and current estimates, EOS, Trans. Am. Geophys. Union, 85, 48, 509-512, 2004. 